\title{
The Social Origins of Cooking and Dining in Early Villages of Western Asia
}

\author{
By KATHERINE I. WRIGHT ${ }^{1}$
}

This paper explores social customs of cooking and dining as farming emerged in the earliest villages of Palestine and Jordan (12,650-6850 cal BC). The approach is a spatial analysis of in situ hearths, pits, bins, benches, platforms, activity areas, caches, and ground stone artefacts. Mortars, pestles, and bowls first appear in significant numbers in base camps of semi-sedentary Natufian hunter-gatherers. Elaborate and decorated, these artefacts imply a newly formal social etiquette of food-sharing. They were used within houses, near hearths, and in outdoor areas. The earliest farmers of the Khiamian and Pre-Pottery Neolithic A used simple, mostly undecorated, ground stone tools. One-room houses were often fitted with a hearth and a small mortar in the centre, features that also occur in outdoor areas. In the Early and Middle Pre-Pottery Neolithic B, firepits, milling stations, and storage features were placed on porches and outdoor areas near house doors. These areas formed a transition zone between house and community, where food preparation provided opportunities for social contacts. The most private rooms in houses were supplied with benches, platforms, and decorated hearths, and probably sheltered household meals. In the Late PPNB, when some villages grew to unprecedented sizes, storage, and cooking facilities were placed in constricted, private spaces comparatively hidden from community view. Numerous milling tools and multiple milling stations in individual houses suggest intensification of production of prepared foods. It is argued that adult women bore the brunt of the increased labour and that these activities placed them under new restrictions of daily activity and visibility in relation to village communities.

\section{INTRODUCTION}

In the vast literature on the emergence of agriculture and village life in the Middle East, very little has been said about the social customs by which early farmers prepared and consumed food. Yet meals are everyday rituals of profound importance in social life, structuring daily social intercourse and reinforcing cultural values. Sometimes, cooking and dining are mainly social rituals in which nutrition is of little significance (Farb \& Armelagos 1980; Hattox 1985; Mead 1947). In an English house or in a Bedouin tent, a stimulating drink facilitates conversation and conveys hospitality. The social act of serving and sharing coffee or tea, according to precise cultural rules of procedure, is more to the point than mere thirst.

${ }^{1}$ Institute of Archaeology, University College London, 31-34 Gordon Square, London WC1B OPY

Received September 1999. Accepted February 2000.
Ethnographies document a breathtaking diversity in food customs. Staples, equipment, techniques, and organisation of activities all vary widely. Food choices, processing, cooking, dining, 'table manners', and hospitality serve many social functions. They enculturate individuals, encode social relationships, define social groupings, mark changes of status and role, and symbolise other elements of social structure (Douglas 1972; 1984; Levi-Strauss 1969; 1978; Messer 1984; Richards 1939). Food customs are central to many kinds of social negotiations (the politics of gastronomy; Appadurai 1981). For example, individuals or groups may negotiate status by using hospitality as an opening gambit in reciprocity, which in turn can work for or against equality (cf Sahlins 1972). Food customs can be used to legitimise, undermine, or manipulate social or political hierarchies. High status is often conspicuously marked by specially-prepared or exotic foods (cuisines), eaten in elaborate settings guided by 
prescribed rituals such as feasts or banquets (eg, Firth 1957; Goody 1982; Rappaport 1968).

Archaeologists have only just begun to explore such issues (Clark \& Blake 1993; David et al. 1988; Davidson 1997; Forest 1996; Gosden \& Hather 1999; Hastorf 1991; 1998; Joffe 1998; Sherratt 1981; Speth 1990; Wiessner \& Schiefenhovel 1996; Wright forthcoming). Most discussions of the food habits of early farmers centre on ecology and diet. What can archaeology tell us about social customs of cooking and dining in the houses and villages of early farmers? How did these customs emerge and change through time?

Since 1980, excavations have shed new light on the earliest known farming villages, which lie in Palestine and Jordan (the southern Levant) and evolved between 12,650 and $6850 \mathrm{cal} \mathrm{BC} \mathrm{(Fig.} \mathrm{1;} \mathrm{Table} \mathrm{1;} \mathrm{Banning} \mathrm{\&}$ Byrd 1987; Bar-Yosef \& Gopher 1997; Bar-Yosef \& Valla 1991; Byrd 1989; forthcoming; Edwards 1991; Dollfus forthcoming; Garrard 1999; Gebel et al. 1997a; 1997b; Kafafi \& Rollefson 1994; 1995; Kuijt 1995; Mahasneh 1997; Nissen et al. 1987; Rollefson 1997 and passim; Rollefson et al. 1990; 1992; Waheeb \& Fino 1997). Drawing on space syntax and household archaeology (Hillier \& Hanson 1984; Kent 1990), Banning (1996) and Byrd (1994) argue that early south Levantine villages evolved from open houses with easy access between house and community, to more structured settlements with sharper distinctions between public and private space. If so, how was food preparation organised spatially and socially, between household and community? Which resources and activities were shared and which were private? Were cooking facilities integrated into living quarters or detached from them? Did early villagers have rooms specifically designed for preparing food (kitchens)?

\section{METHODS AND ASSUMPTIONS}

This paper presents a spatial analysis of in situ storage bins, pits, ground stone tools, vessels, hearths, ovens, firepits, pavings, artefact clusters, caches, and (to some extent) middens in villages of the Natufian and Pre-Pottery Neolithic. The results grew out of a preliminary study of food processing at some 25 sites (Wright 1992, table 1-1). A number of these projects are drawing to a close and the publications are in progress. Thus, newly-available stratigraphic evidence makes it possible to attempt a synthesis of how and where early farmers prepared and consumed food within villages.

The analysis entails several working assumptions and caveats concerning scope:

1. I assume that the artefacts and features listed above were used for preparing, storing, or consuming food. But it is not necessary to assume that it was exclusively so. These artefacts and features were undoubtedly used for a variety of other purposes unrelated to food.

2. The analysis is strictly limited to preserved artefacts and features suggesting pounding, mixing, milling (=grinding), cooking, transporting, serving, storing, and consuming food within villages. In short, activities involving perishable tools or off-site procedures are not discussed here and a number of tasks (eg, harvesting, butchery) are not included in the analysis.

3. My focus is on broad cultural patterns of food preparation, not diets, nutrition, or specific foods. Organic remains such as seeds and animal

TABLE 1: ABSOLUTE CHRONOLOGY FOR THE PREHISTORIC SOUTHERN LEVANT*

\begin{tabular}{lll}
\hline Period & Approximate dates BP & Approximate calibrated dates (cal BC) \\
\hline Early Natufian & $14,600-13,200$ & $12,650-11,250$ \\
Late Natufian & $13,200-12,400 / 000$ & $11,250-10,450 / 050$ \\
Khiamian \& Pre-Pottery Neolithic A & $12,400 / 000-10,750$ & $10,450 / 050-8800$ \\
Early Pre-Pottery Neolithic B & $10,750-10,250$ & $8800-8300$ \\
Middle Pre-Pottery Neolithic B & $10,250-9500$ & $8300-7550$ \\
Late Pre-Pottery Neolithic B & $9500-8800$ & $7550-6850$ \\
Pre-Pottery Neolithic C & $8800-8200$ & $6850-6250$ \\
Late Neolithic & $8200-7400$ & $6250-5450$ \\
Chalcolithic & $7400-6300$ & $5450-4350$ \\
\hline
\end{tabular}

"Based on CALIB 3.0 and OxCal v.2.18 figures are rounded off to the nearest 20 years 
10. K. Wright SOCIAL ORIGINS OF COOKING \& DINING, EARLY VILLAGES, WESTERN ASIA

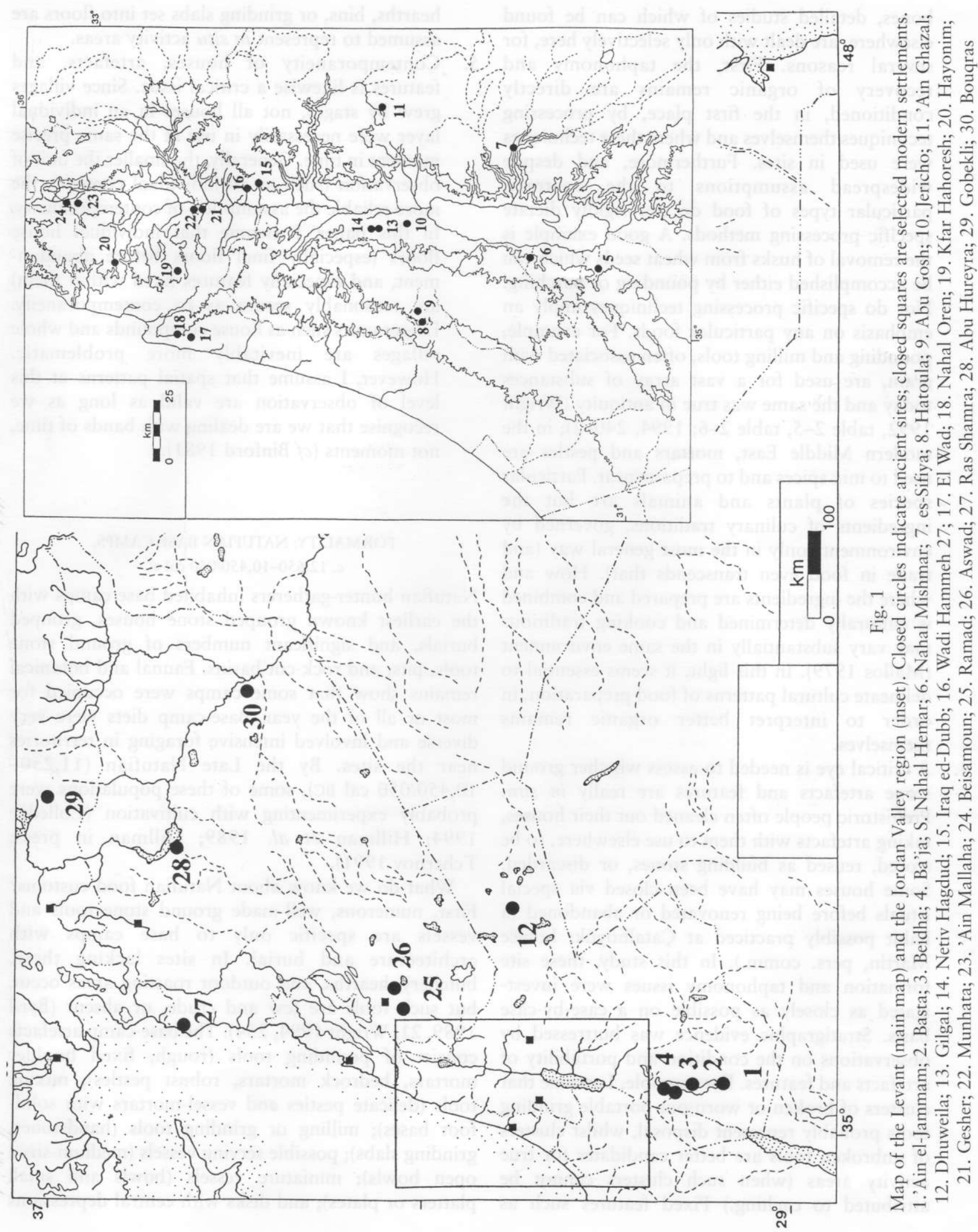


bones, detailed studies of which can be found elsewhere, are dealt with only selectively here, for several reasons. First, the taphonomy and recovery of organic remains are directly conditioned, in the first place, by processing techniques themselves and where these techniques were used in sites. Furthermore, and despite widespread assumptions to the contrary, particular types of food do not rigidly dictate specific processing methods. A good example is the removal of husks from wheat seeds which can be accomplished either by pounding or parching. Nor do specific processing techniques imply an emphasis on any particular foods. For example, pounding and milling tools, often associated with grain, are used for a vast array of substances today and the same was true in antiquity (Wright 1992, table 2-5, table 2-6; 1994, 240-2); in the modern Middle East, mortars and pestles are used to mix spices and to prepare meat. Particular species of plants and animals are but the ingredients of culinary traditions, governed by environments only in the most general way (and trade in food even transcends that). How and where the ingredients are prepared and combined is culturally determined and cooking traditions may vary substantially in the same environment (Mallos 1979). In this light, it seems essential to delineate cultural patterns of food preparation, in order to interpret better organic remains themselves.

4. A critical eye is needed to assess whether ground stone artefacts and features are really in situ. Prehistoric people often cleaned out their houses, taking artefacts with them to use elsewhere, to be stored, reused as building stones, or discarded. Some houses may have been closed via special rituals before being renovated or abandoned (a habit possibly practiced at Çatalhöyük; Louise Martin, pers. comm.). In this study, these site formation and taphonomy issues were investigated as closely as possible on a case-by-case basis. Stratigraphic evidence was buttressed by observations on the condition and portability of artefacts and features. For example, I assume that clusters of broken or worn-out portable grinding tools probably represent disposal, whilst clusters of unbroken tools are better candidates for true activity areas (when such clusters cannot be attributed to caching.) Fixed features such as hearths, bins, or grinding slabs set into floors are assumed to represent in situ activity areas.

5. Contemporaneity of houses, artefacts, and features is likewise a critical issue. Since villages grew by stages, not all houses in an individual layer were necessarily in use at the same precise moment in time. Generally, the smaller the unit of observation (such as an individual context), the more reliable the assumption of contemporaneity. In this paper, I assume that individual house floors (especially final floors before abandonment, and especially features fixed within them) are reasonably secure as to contemporaneity. Larger units such as house compounds and whole villages are inevitably more problematic. However, I assume that spatial patterns at this level of observation are valid as long as we recognise that we are dealing with bands of time, not moments ( $c f$ Binford 1981).

\section{FORMALITY: NATUFIAN BASE CAMPS,}

$$
\text { c. } 12,650-10,450 / 050 \mathrm{cal} \text { BC }
$$

Natufian hunter-gatherers inhabited base camps with the earliest known grouped stone houses, grouped burials, and significant numbers of ground stone tools, pits, and rock-cut basins. Faunal and botanical remains show that some camps were occupied for most or all of the year. Base-camp diets were very diverse and involved intensive foraging in territories near the sites. By the Late Natufian $(11,250-$ $10,450 / 050 \mathrm{cal} \mathrm{BC})$, some of these populations were probably experimenting with cultivation (Colledge 1994; Hillman et al. 1989; Hillman in press; Tchernov 1991).

What do we know about Natufian food customs? First, numerous, well-made ground stone tools and vessels are specific only to base camps with architecture and burial. In sites lacking these, butchery, hearths, and outdoor roasting areas occur, but such tools are few and crude, or absent (Byrd 1989, 21; Wright 1994, 254). The base-camp artefacts consist of pounding tools (rough, fixed boulder mortars, bedrock mortars, robust pestles); mixing tools (delicate pestles and vessel-mortars with solidfoot bases); milling or grinding tools (handstones, grinding slabs); possible serving vessels (medium-sized open bowls); miniature vessels (bowls and small platters or plates); and disks with central depressions 


\section{K. Wright SOCIAL ORIGINS OF COOKING \& DINING, EARLY VILLAGES, WESTERN ASIA}

(Fig. 2). Second, the base-camp assemblages are strikingly similar in composition, type frequencies, shapes, and styles from one site to another (Figs $3 \&$ 4). In particular, pestles, mortars, and vessels from different camps have similar ranges of forms and decorations, including even specific motifs such as carved meander designs and animal heads (Fig. 2; Belfer-Cohen 1988, fig. 3; 1991, fig. 7; Edwards 1991, fig. 7; Noy 1991, figs 3-4, 6; Perrot 1966a, figs 15 \& 17).

The best spatial data come from 'Ain Mallaha, Wadi Hammeh 27, Hayonim Cave and Hayonim Terrace (Bar-Yosef 1991; Dollfus forthcoming; Edwards 1991; Perrot 1966a; Valla 1988, 1991; Valla et al. $1986 ; 1989 ; 1991)$.

\section{Early Natufian}

In Early Natufian base camps, most evidence for food preparation comes from inside houses, whilst evidence for the use of outdoor areas is so far limited. Thus, in early levels at Hayonim Cave, processing tools were found almost exclusively inside structures near hearths (Bar-Yosef 1991). At Early Natufian 'Ain Mallaha, four superimposed structures, an additional house, two smaller structures, and an open area were excavated (Fig. 5a). Clusters of ground stone tools were found in most structures. Hearths were found in only three houses, but in each case (Houses 131, 1, 62 ), clusters of pestles and vessels were found near the hearths. Most hearths were circular and carefully built, lined with stone slabs forming a small wall

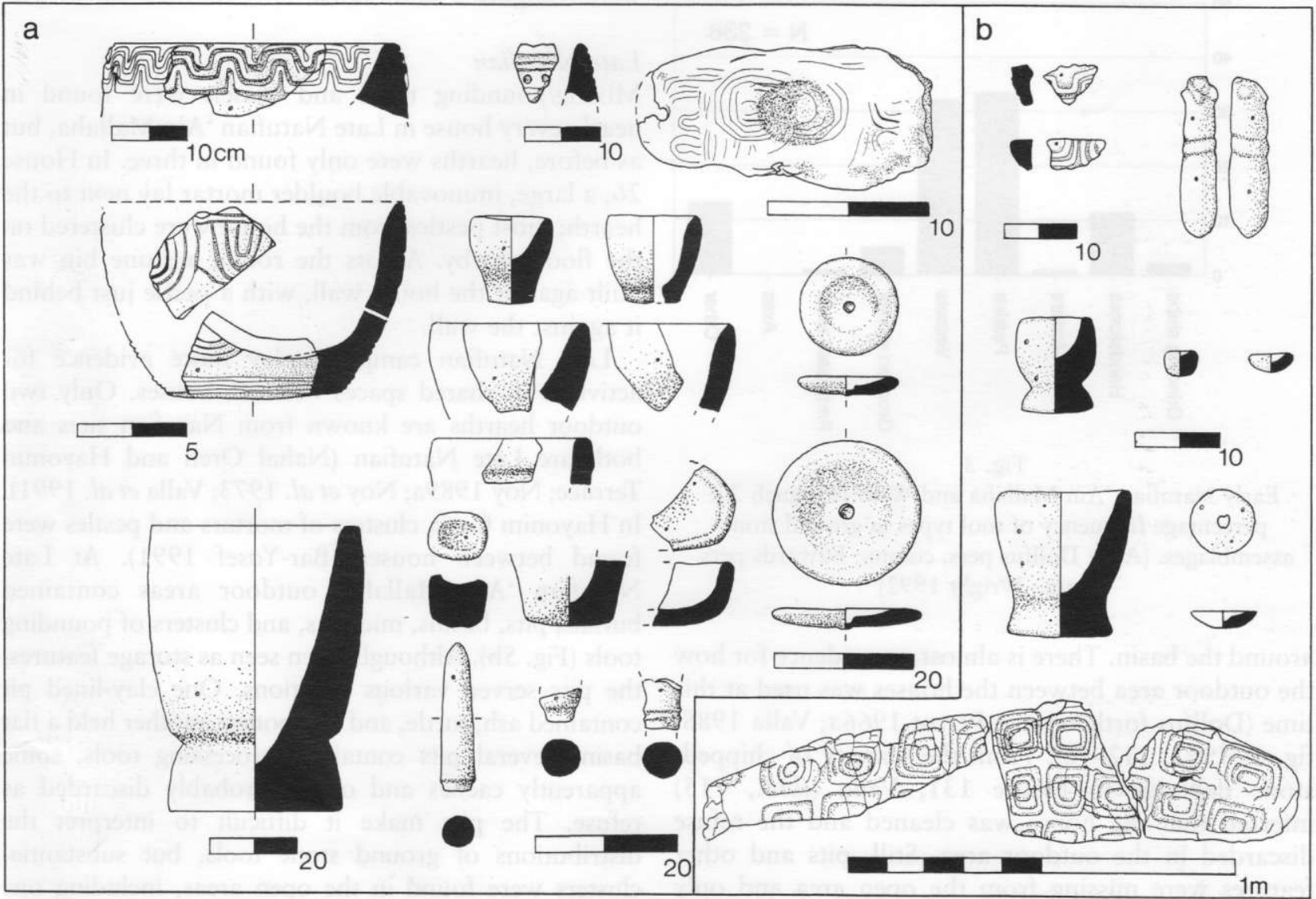

Fig. 2

Natufian ground stone artefacts. a. 'Ain Mallaha; b. Wadi Hammeh 27. Bottom right: incised wall stones from inside a house. (Redrawn from: a. Perrot 166a, figs 15, 16, 18, 21; b. Edwards 1991, figs 6, 10) 
(a)

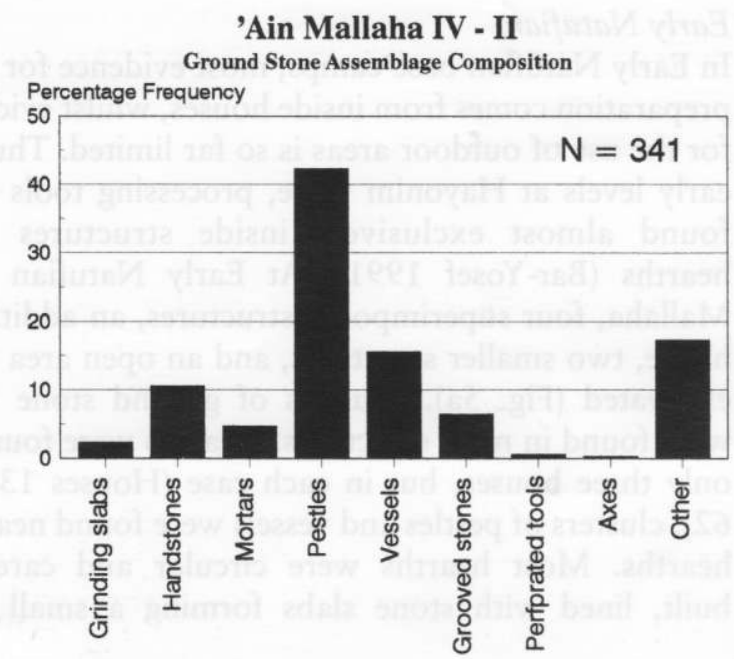

(b)

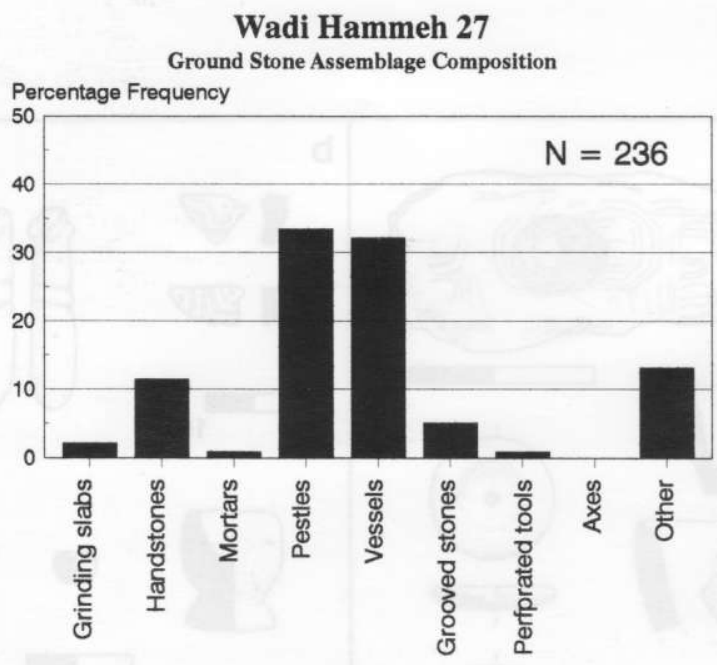

Fig. 3

Early Natufian 'Ain Mallaha and Wadi Hammeh 27: percentage frequency of tool types in ground stone assemblages. (After Dollfus pers. comm.; Edwards pers. comm.; Wright 1992)

around the basin. There is almost no evidence for how the outdoor area between the houses was used at this time (Dollfus forthcoming; Perrot 1966a; Valla 1988, fig. 3; 1991, 112-16). From the scarcity of chippedstone debitage in House 131, Valla (ibid., 115) inferred that the house was cleaned and the refuse discarded in the outdoor area. Still, pits and other features were missing from the open area and only isolated pestles and grinding slabs were found there.

Two houses and an exterior space were excavated at Early Natufian Wadi Hammeh 27 (Edwards et al.
1988; Edwards 1991). The outdoor space revealed mainly traces of curved stone features, burials, and some burned areas. Each house interior revealed ashy areas defined as hearths, along with with curved stone features (benches?); one house also had a small platform. Despite extensive flotation for maximum recovery of organic remains, all plants from the excavation came from within the structures. Nearly all contexts that produced plant remains also had ground stone processing tools (Table 2) (Colledge 1994, table 5.3; Wright 1992). In House XX E/F, high concentrations of plant remains were found next to a hearth. Two caches of processing tools were found near the house wall. Cache 1 held two vessel-mortars with two pestle-mixers stacked on top of them. A second pair of pestles was found stacked together nearby. Cache 2 contained two vessel-mortars, two handstones and one pestle-mixer inside one mortar. The caches suggest that pairs of processing-tool sets were recognised as toolkits.

\section{Late Natufian}

Mixing/pounding tools and vessels were found in nearly every house in Late Natufian 'Ain Mallaha, but as before, hearths were only found in three. In House 26 , a large, immovable boulder mortar lay next to the hearth; most pestles from the house were clustered on the floor nearby. Across the room, a stone bin was built against the house wall, with a pestle just behind it against the wall.

Late Natufian camps display more evidence for activities in shared spaces between houses. Only two outdoor hearths are known from Natufian sites and both are Late Natufian (Nahal Oren and Hayonim Terrace; Noy 1989a; Noy et al. 1973; Valla et al. 1991). In Hayonim Cave, clusters of mortars and pestles were found between houses (Bar-Yosef 1991). At Late Natufian 'Ain Mallaha, outdoor areas contained burials, pits, basins, middens, and clusters of pounding tools (Fig. 5b). Although often seen as storage features, the pits served various functions. One clay-lined pit contained ash, turtle, and fish bones; another held a flat basin. Several pits contained processing tools, some apparently caches and others probably discarded as refuse. The pits make it difficult to interpret the distributions of ground stone tools, but substantial clusters were found in the open areas, including one cluster with six mortars and three pestles in an area of 1 x $1 \mathrm{~m}$ (Dollfus forthcoming; Perrot 1966a, figs 10 \& 14; Valla 1988; Valla 1991, 116-9). 
Wadi Hammeh 27: Early Natufian (Ref: Edwards 1991; pers. comm.; Colledge 1994; Wright 1992)

Cache 1 on House Floor (House XXE/F, Phase 1, Context E3-3)

2 vessel-mortars each with solid foot, one small, one larger; 1 carved-animal pestle with one pounding surface (mixer) (stacked on larger mortar); 1 cylindrical pestle with one pounding surface (stacked on larger mortar); 2 cylindrical pestles each with 2 pounding surfaces (stacked together); 1 pestle fragment; 1 vessel fragment

Cache 2 on House Floor (House XXE/F, Phase 1, Context EH4-1)

2 larger vessel-mortars with solid foot; 2 discoidal handstones; 1 cylindrical pestle with one pounding surface (mixer)

Pit in House Floor (House XXE/F, Phase 1, Context F2-4)

$1 \mathrm{knobbed} / \mathrm{handled}$ pestle with one pounding surface (mixer); 1 conical pestle with two pounding surfaces, 1 miniature platter; 1 unidentifiable fragment

Occupation deposit above floor (House XXE/F, Phase 1, D3-4)

1 small vessel-mortar with solid foot; 1 miniature bowl; 1 conical pestle with one use surface (mixer); 3 pestle fragments

Occupation deposit above floor (House XXE/F, Phase 1, F2-2)

1 discoidal handstone with 2 grinding surfaces; 1 cylindrical pestle with 2 pounding surfaces; 1 conical pestle with one use surface; 1 miniature platter; 1 shaft straightener, 2 unidentifiable fragments

Occupation deposit above floor (House XXE/F, Phase 1, D3-3)

1 vessel rim fragment

Occupation deposit above floor (House XXE/F, Phase 1, D5-1)

1 incised vessel rim; 1 pestle fragment

Occupation deposit above floor (House XXE/F, Phase 1, D11-1)

1 pestle; 1 pestle fragment; 1 handstone fragment, 1 vessel body sherd

plant remains: many unidentifiables; legumes lentil, mallow

plant remains: 9 'Species X'

plant remains:

unidentifiables, legumes,

Liliaceae

plant remains:

unidentifiables; mallow,

legumes

plant remains:

unidentifiables; indet.

legume

Occupation deposit above floor (House XXE/F, Phase 2, F2-3)

1 small vessel-mortar with solid foot; 1 miniature open bowl; 1 loaf-shaped handstone with two grinding surfaces; 1 unidentifiable fragment

Occupation deposit above floor (House XXE/F, Phase 2, F2-6)

None

Occupation deposit above floor (House XXE/F, Phase 2, F2-7)

1 miniature platter; 1 pestle fragment; 1 unidentifiable fragment

plant remains: wild barley, legumes, mallow, Lolium

plant remains: 1 pistachio fragment

plant remains: $1-2$ pistachio fragments

Occupation deposit above floor (House XXE/F, Phase 3, F2-5)

1 discoidal handstone with 1 grinding surface

Occupation deposit above floor (House XXE/F, Phase 3, F2-11)

1 vessel rim fragment; 1 vessel body sherd

Ain Mallaha: Early Natufian (Ref: Dollfus pers. comm.; Perrot 1966a; Valla 1998: fig. 3; Valla 1991)

Cluster 4140: 1 grinding slab, 2 shaft straighteners, 4 hammerstones;

Cluster 4141: 1 pestle, 1 hammerstone

Ain Mallaha: Late Natufian (Ref: Dollfus pers. comm.; Perrot 1966a; Valla 1988: fig. 3; Valla 1991)

Cluster on House Floor (House 26, Level I)

1 fixed boulder mortar, 17 pestles, 3 discoidal handstones, 1 hammerstone; (most pestles

found in cluster near boulder mortar and hearth; 1 behind stone bin) 
(a)

(a)

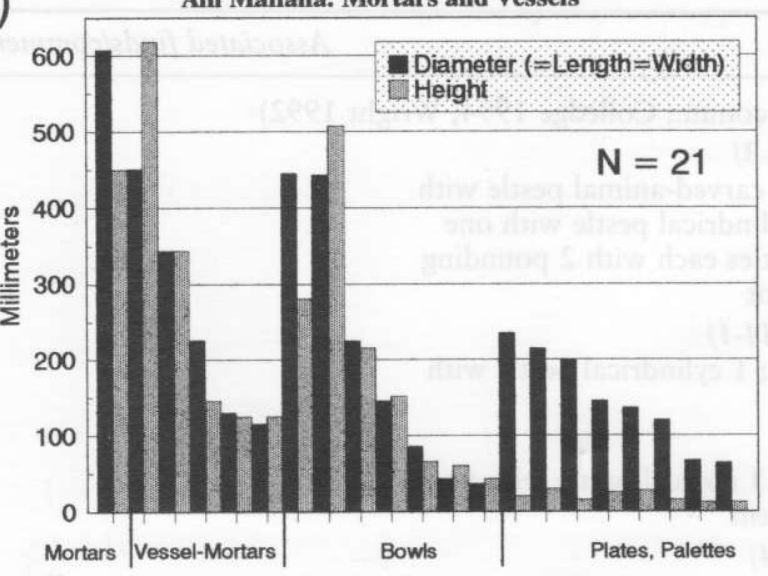

(b)

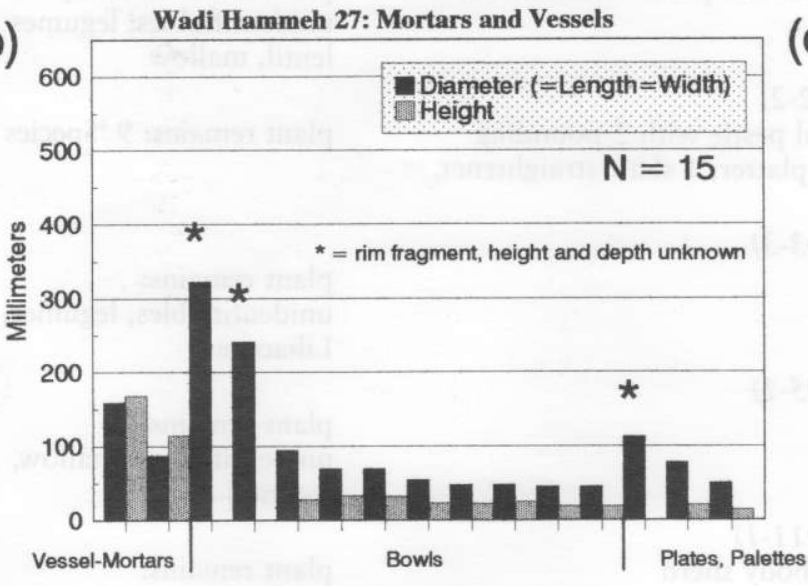

(c)

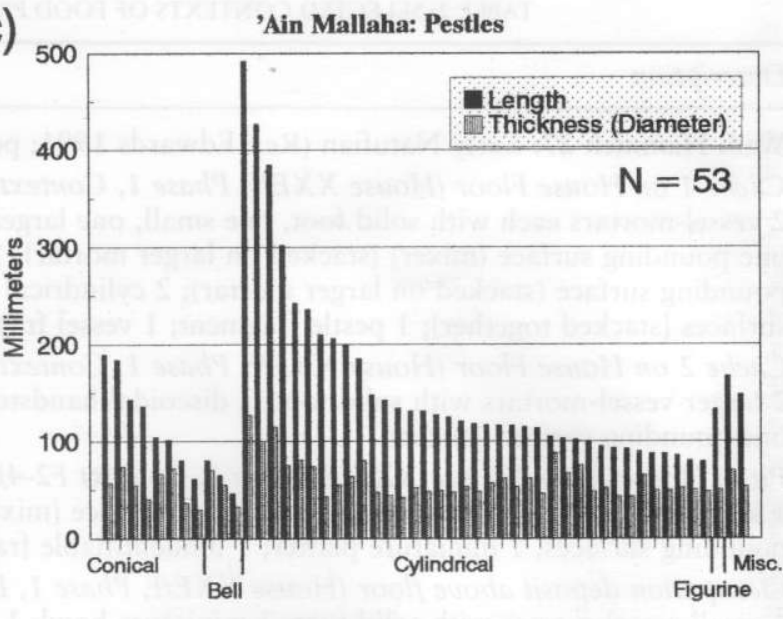

(d)

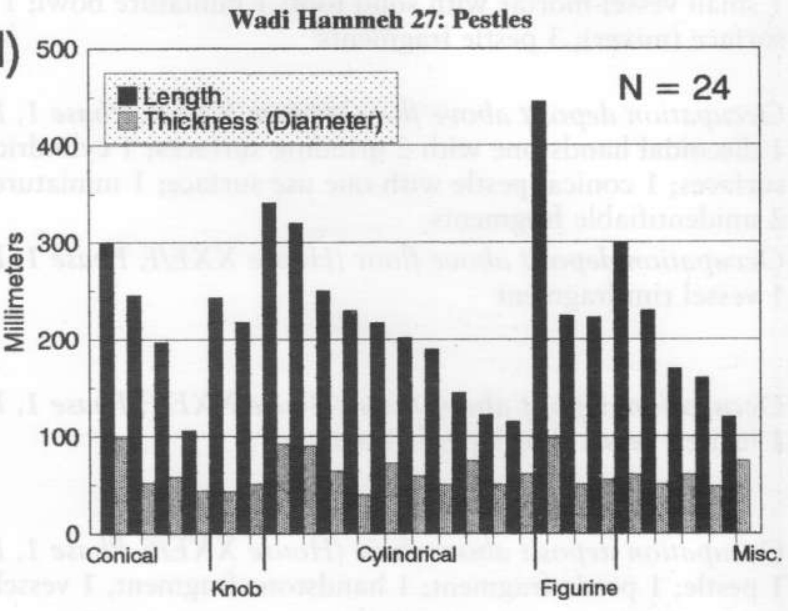

Fig. 4

Comparison of sizes of mortars, vessels, and pestles from Early Natufian 'Ain Mallaha and Wadi Hammeh 27. Each tick on the $\mathrm{x}$-axis represents an individual artefact. All artefacts are complete except where noted.

(After Dollfus pers. comm.; Edwards pers. comm.; Wright 1992)

\section{Discussion}

Natufian hunter-gatherers used mortars, pestles, and bowls inside shelters, near hearths when these were present. These tools were sometimes stored in caches near house walls. Hearths, pits for storage or refuse, and clusters of mortars and pestles were also placed in outdoor areas, although these areas are mainly known from Late Natufian sites. Settings for eating and drinking undoubtedly varied according to season and occasion, but since Natufian base camps were probably occupied year-round, we can infer that in winter or bad weather, pounding, mixing, cooking and dining took place inside the shelters.
Since Natufian houses never exceeded $28 \mathrm{~m}^{2}$ in area, processing and cooking would have involved small groups of only a few individuals. Pairs of mortar-pestle sets found in caches suggest that either: (1) two persons were involved in pounding and mixing; (2) pounded foods were deemed to require two separate mortar-pestle sets; (3) a backup set of tools had to be available in the event of breakage; or (4) food preparation of this kind entailed some other logic involving pairs ( $c f$ Levi-Strauss 1963, 35).

The composition of groups preparing food in the houses could have varied. Flannery (1972, 30-4) suggested that 'Ain Mallaha and other Natufian base 
camps were organised as circular house compounds in which adult women and their children occupied their own huts. As a test of this hypothesis, he proposed that ground stone tools - believed to represent women's activities - might be found in some houses but not others in a given compound. But most houses at Mallaha, Wadi Hammeh 27, and Hayonim have some of these tools, in combinations suggesting working toolkits; differences between houses cannot be discerned.

Natufian ground stone tools were curated, labour intensive to produce, and decorated with carvings and sometimes paint. They suggest formality in foodsharing and an element of social ritual surrounding it. Indeed, ground stone tools figured in mortuary ritual. At Nahal Oren, Hayonim Cave, El Wad, and Wadi Hammeh 27, mortars, pestles, and other ground stone items were found in graves. However, there is no cooccurrence of these items with group or single burial, gender, or age and, in particular, no link between adult women and these items (Byrd \& Monahan 1995; Wright 1992).

Formality, decoration, and ritual are widely believed to highlight social boundaries, tensions, or situations perceived as dangerous to the social order (Douglas 1966, 2-3, 34-5; Malinowski 1954; Radcliffe-Brown 1952, 147-50). If so, what tensions might have existed in the Natufian? Territoriality, semi-sedentism, and rising birth rates would have encouraged more intensive exploitation of immediately accessible foods (Bar-Yosef \& Belfer-Cohen 1991; Hillman \& Davies 1990), as well as technical innovations in preparing food (Wright 1994). A growing commitment to particular sites may have interfered with fission, the classic means by which mobile hunter-gatherers resolve conflicts (Turnbull 1965; Lee \& DeVore 1968, 9, 156-7). Such a situation would have exerted pressures on traditional social rules of food-sharing. A formal aesthetic and new rules of etiquette in food-sharing may have been an alternative means of resolving territorial conflicts emerging from reduced mobility. Conspicuous consumption as a means of expressing and settling rivalries is well documented among semi-sedentary hunter-gatherers (eg, Codere 1950). The similarity of ground stone tools and vessels from one base camp to another also suggests that similar rules of foodsharing were recognised between camps.

One might ask whether the base-camp ground stone artefacts suggest special occasions (feasting)
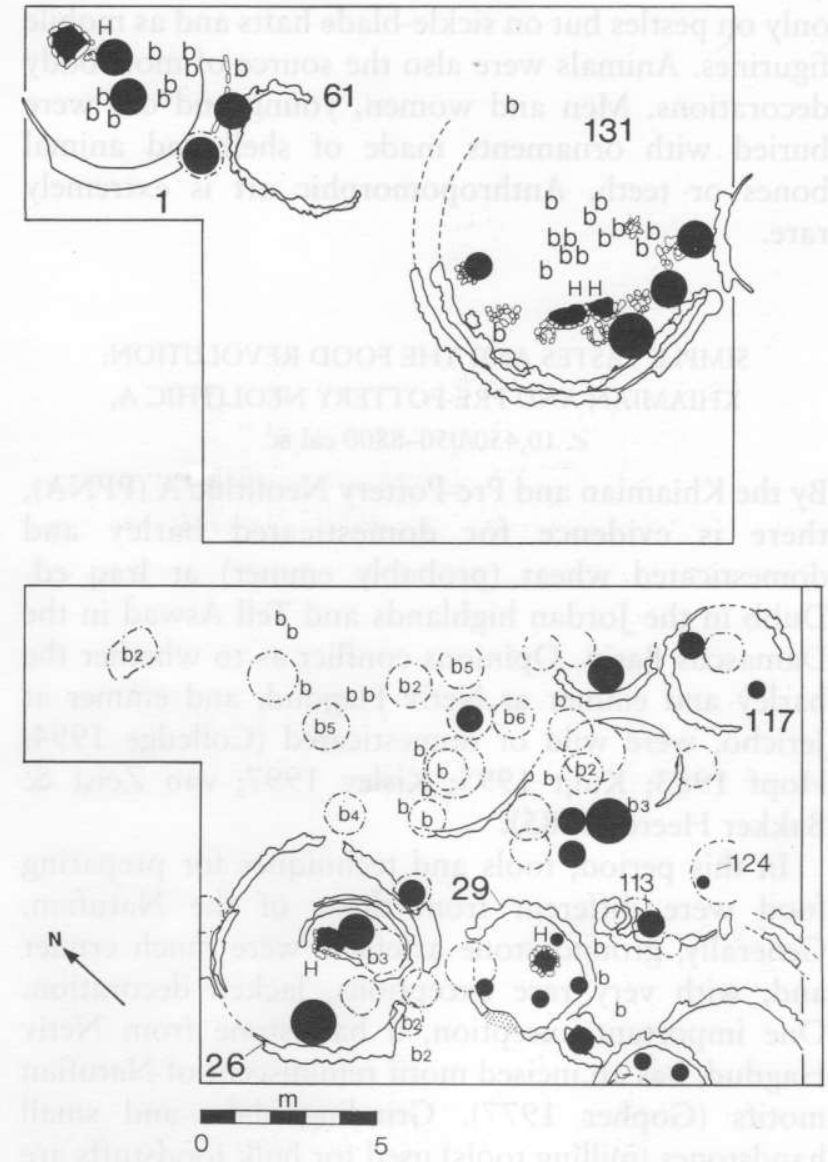

Fig. 5

'Ain Mallaha. Plans of the base camp in the Early Natufian (top); and the Late Natufian (bottom) showing major structures and features (numbered), hearths (darkened areas labelled $\mathrm{H}$ ), pits (broken lines) and human remains; (b) Closed circles indicate major clusters of mortars, pestles, grinding slabs, handstones. Not all such clusters are shown. (Redrawn from Valla 1981, figs 2, 4; data from Valla 1988, fig. 3 and Dollfus pers. comm.)

involving symbolism and ritual, perhaps associated with burial. It seems likely that this was one, but not the only, social context in which the tools were used. Finally, one might enquire as to the symbolic meaning of the decorated ground stone tools. Since symbols are the arbitrary assignment of meaning to form, there is little we can say about the specific referents of the motifs. However, the motifs that appear on the tools also appear on other artefacts and therefore were not unique to processing equipment. Meander designs occur on both bowls and on house walls (Fig. 2). Animal motifs dominate Natufian art and appear not 
only on pestles but on sickle-blade hafts and as mobile figurines. Animals were also the source of most body decorations. Men and women, young and old were buried with ornaments made of shell and animal bones or teeth. Anthropomorphic art is extremely rare.

\section{SIMPLE TASTES AND THE FOOD REVOLUTION: KHIAMIAN AND PRE-POTTERY NEOLITHIC A, c. $10,450 / 050-8800 \mathrm{cal} \mathrm{BC}$}

By the Khiamian and Pre-Pottery Neolithic A (PPNA), there is evidence for domesticated barley and domesticated wheat (probably emmer) at Iraq edDubb in the Jordan highlands and Tell Aswad in the Damascus Basin. Opinions conflict as to whether the barley and emmer at Netiv Hagdud, and emmer at Jericho, were wild or domesticated (Colledge 1994; Hopf 1983; Kuijt 1995; Kislev 1997; van Zeist \& Bakker Heeres 1985).

In this period, tools and techniques for preparing food were different from those of the Natufian. Generally, ground stone artefacts were much cruder and, with very rare exceptions, lacked decoration. One important exception, a handstone from Netiv Hagdud, has an incised motif reminiscent of Natufian motifs (Gopher 1977). Grinding slabs and small handstones (milling tools) used for bulk foodstuffs are much more common in these assemblages. They imply a new emphasis on more finely ground foods, which maximise availability of nutrients by exposing more surface area of the product (Fig. 6a-b, f; Wright 1994). Slabs with small mortar surfaces ('cupholes') were probably used with small pestles for processing small quantities (Fig. 6e). Stone vessels were mainly rough, shallow open bowls, about $200 \mathrm{~mm}$ in diameter with relatively little variation; some were certainly used for grinding. Finer bowls are very rare (Fig. 6c-d; Dorrell 1983; Gopher 1997, 159-60; Noy 1979 , fig. 4). Basket fragments testify to the use of perishable vessels (Schick 1997, 197-8).

\section{Netiv Hagdud}

Most PPNA villages consisted of one-room oval houses of about 3-8 $\mathrm{m}$ in diameter, irregularly arranged around open areas. At Netiv Hagdud, some 20 structures and an outdoor area were exposed (Fig. 7). House interiors were fitted with pavings of flat stones associated with hearths of ash and burned stones near the room's centre (Houses 21, 8, 40). Most houses also had a fixed cuphole slab set into the floor nearby. Small numbers of pestles, handstones, and vessels were found on most house floors. Pits and stone bins were placed against house walls. In one house, a stone bin held a cache of stored tools composed of three shaft straighteners, two handstones, and three grinding slabs. House 8 , the sole house with an interior partition wall, produced 54 ground stone items, including three fixed cuphole slabs, handstones, pestles, a polished axe, and broken bowls. Fragments of three adult skulls were also found on this floor (burials were also found underneath other house floors).

The same range of features was also found in outdoor areas at Netiv Hagdud: stone bins, mudbrick bins, fixed cuphole slabs, clusters of handstones and pestles, a hearth and paving, and burials. Nearly all contexts that produced plant remains also produced ground stone tools. These contexts were both inside and outside of houses (Table 3) (Bar-Yosef \& Gopher 1997, 46, fig. 3.19; Gopher 1997, fig. 5.18; Kislev 1997).

\section{Gilgal}

At Gilgal, of 13 oval houses, some had hearths identified by ash, clay borders, and burnt gravel. Cuphole slabs were said to occur on the floor of each house, along with pestles, grinding slabs, handstones, and vessels. House 11 held a storage feature with oats, barley, acorns, and pistachios near the door; many processing tools were found on the opposite side of the house, along with basket fragments (Noy 1979, 233-4; 1989b; Noy et al. 1980, 64-5, pls 2 c \& 3a).

\section{Nahal Oren}

Of 20 houses at Nahal Oren, most contained a circular stone-bordered hearth, often with a cuphole slab nearby. Pestles, grinding slabs, and bowls were found on the floors (Noy et al. 1973; Stekelis \& Yizraeli 1963, pls a-c).

\section{Iraq ed-Dubb}

Of three structures at Iraq ed-Dubb Cave, Structure I had high densities of charred wheat and barley (wild and domestic), legumes, pistachio, fig, and a pit with wild einkorn. In Structure II, a central hearth had a cuphole slab next to it, whilst a deep pit was found next to one wall (Colledge 1994, 163, table 5.4; Kuijt 1995).

\section{Gesher}

Structures were poorly preserved at Gesher (Garfinkel 1993), but one house had a hearth with a fixed cuphole slab next to it. A pit within the structure held a cache of handstones and a basalt bowl. Just outside of the house, Garfinkel (1993, 493) found 'dozens of basalt and limestone vessels, pestles, grinding slabs, rounded grinding stones and hammerstones.' 

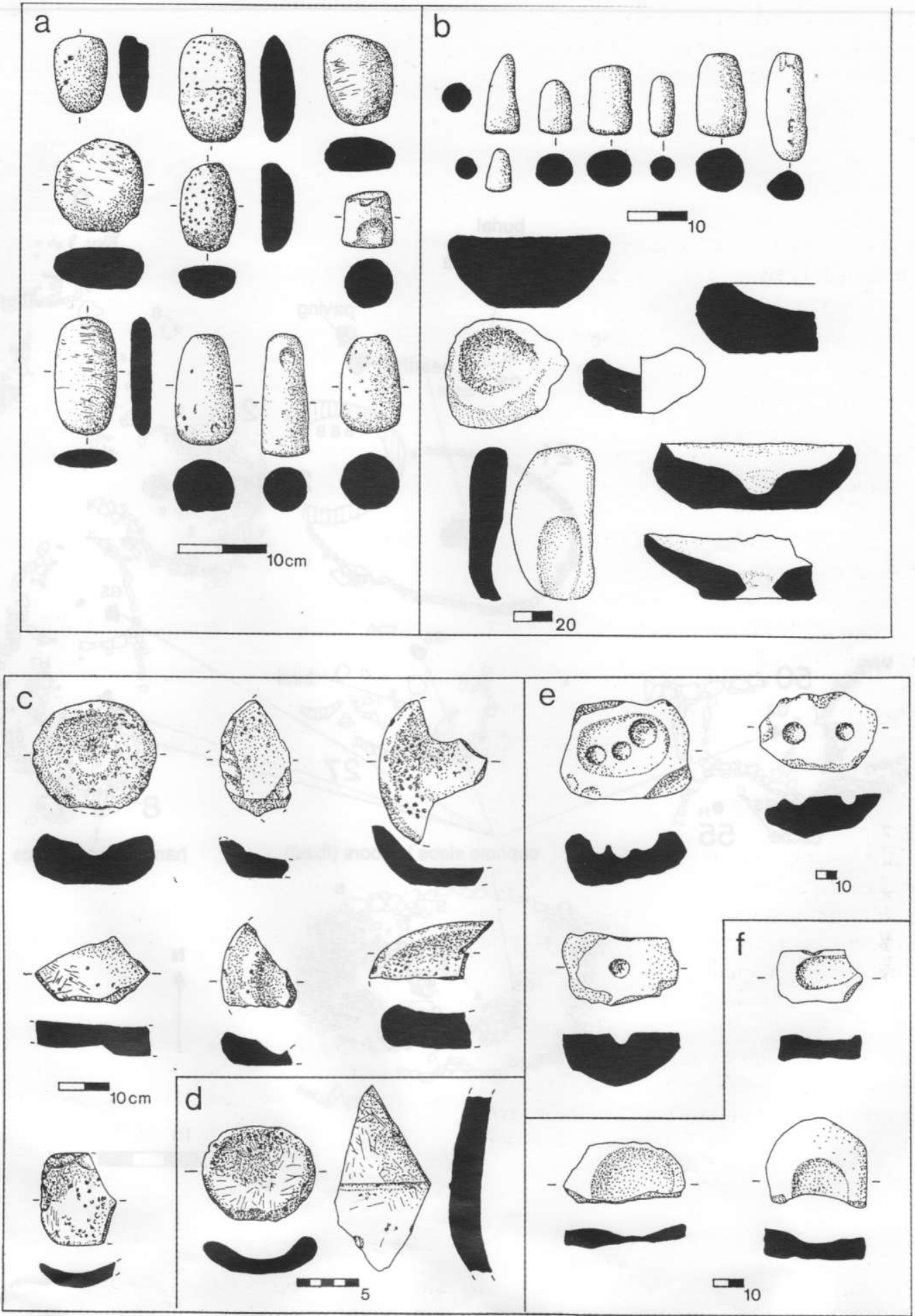

Fig. 6

Pre-Pottery Neolithic A ground stone artefacts. a. handstones and pestles, Netiv Hagdud; b. pestles, bowls, grinding slabs, and cupmark slabs, Jericho; c-d. bowls, Netiv Hagdud; e. cuphole slabs, Netiv Hagdud; f. grinding slabs, Netiv Hagdud. (Redrawn from: a. c-e. Gopher 1997, figs 5.1, 5.3, 5.5, 5.18, 5.19; b. Dorrell 1983, figs 220, 221) 


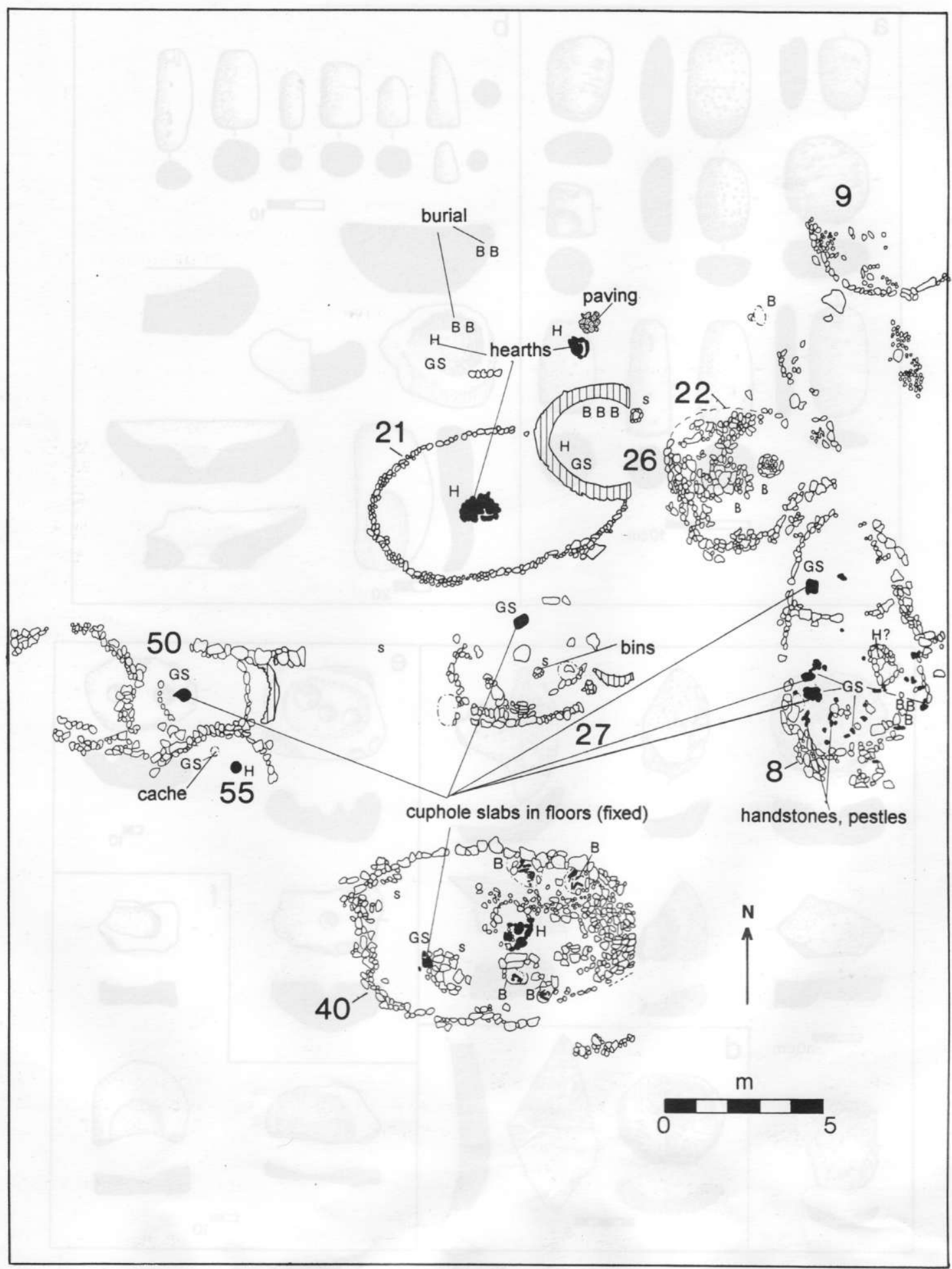

Fig. 7

Netiv Hagdud (PPNA). Key: H=hearth; GS=ground stone artefacts; s=storage bin or feature; $\mathrm{B}=$ human remains or burials. (After Bar-Yosef \& Gopher 1997, 43-58, fig. 3.3) 


\section{Hatoula}

At Hatoula, the interior of the only well-preserved house (of two) revealed a pit-hearth, a slab with cupholes, a pit filled with small pebbles, and a mortar and pestle found against a wall near the house door. Outside the structure, a cluster of heavy, immobile mortars and pestles were found (Lechevallier \& Ronen 1985; Lechevallier et al. 1989, 3).

\section{Jericho}

At Jericho, the best exposed house (Area M) was a sunken, one-room, oval mudbrick building about $5 \mathrm{~m}$ in diameter, entered via a walled stone ramp leading downward to a stone threshold on the floor. Ground stone tools and vessels were found on the floor, along with hearths and pits. Jericho is the only PPNA village with a wall, probably built for protection from mudslides (Bar-Yosef 1986). The sole evidence for the use of community space is the Jericho tower. At 30 feet $(c .10 \mathrm{~m})$ in height, with an internal staircase, it is a unique public building of unknown functions, but a bin was built next to it (Kenyon \& Holland 1981; 1983).

\section{Discussion}

Thus, many PPNA houses were supplied with standard fixed facilities arranged in patterned ways. Food preparation tools were both stored and used inside houses. Pits and/or bins, typically one or two per house, were often placed against house walls; caches of portable processing tools were sometimes stored in them. Normally, a single hearth and one fixed cuphole slab next to it dominated the centre of the one room in a house. Clusters of pestles, mortars, handstones, mobile grinding slabs, and vessels have been found on house floors, either near hearths or against house walls. Some houses contained several fixed cuphole slabs and unusually high numbers of processing tools. The hearth-cuphole slab combination suggests that cupholes and pestles were used to process and dispense foodstuffs in small amounts, perhaps flavourings added to bulk foods during cooking or dining (eg, herbs, oils, animal fat, nuts). It is tempting to interpret this as a response to gradually declining dietary diversity (cf Hillman et al. 1989).

Activities conducted in houses also took place in exterior space: storage, milling, cooking, paving (and burial). This cannot be attributed merely to site formation processes. The features include in situ hearths, stone pavings, cuphole slabs, and heavy mortars. Accumulations of unbroken pounding and milling tools (including heavy grinding slabs) occur just outside of houses. They suggest repeated use of specific outdoor areas, possibly by work parties. In terms of food preparation, boundaries between house and common space were quite fluid and remarkably unstructured (Table 3).

With rare exceptions, PPNA ground stone artefacts utterly lack the extent of diversity, workmanship, and decoration that we see in the Natufian. The same is true of hearths, which were often merely areas of ash or burned stones. Clearly, a different set of attitudes to food and dining were at work. The PPNA villages seem to have had little interest in conspicuous displays in preparing and serving food. Despite the presumed profundity of the agricultural 'revolution', cultural practices surrounding meals were remarkably undramatic and low-key. Several possibilities might account for this: (1) the medium of decoration or display was in perishable items; (2) other items of material culture were used to convey social messages at meals (eg, figurines, skulls); (3) extreme simplicity was regarded as the proper aesthetic of cooking and dining. But storage features may be a partial exception to the pattern. Stone-lined bins, relatively rare in Natufian sites, are considerably more ubiquitous in the PPNA. They occur both within and outside of houses and one is linked to the only known public structure, the Jericho tower.

\section{KITCHEN-PORCHES AND HEARTH ROOMS: EARLY-MIDDLE PRE-POTTERY NEOLITHIC B, c. $8800-7550 \mathrm{cal} \mathrm{BC}$}

Sites of the Pre-Pottery Neolithic B (PPNB) ranged from hunting camps to large villages. The village economies were based on cultivated cereals and legumes, hunting and gathering, and, by the Late PPNB, domestic goats and sheep (Garrard 1999; Horwitz et al. 1999). The villages are widely regarded as year round occupations inhabited by fully sedentary groups, but this picture is probably oversimplified. Of the villages, ten provide the best information on food systems: Beisamoun, Munhata and Jericho in the Jordan Valley; 'Ain Ghazal and Abu Gosh in the central highlands astride the valley; and Beidha, Ba'ja, Basta, es-Sifiya, and 'Ain el-Jammam in the south Jordanian highlands.

The PPNB was a period of technological innovation in food preparation. Detailed studies of PPNB ground 
Description

Associated finds/comment

Netiv Hagdud: PPNA Sultanian (Ref: Bar-Yosef \& Gopher 1997; Gopher 1997; Kislev 1997)

Locus 1002: Open area, fill, possibly a soil floor

2 pestles, 2 handstones, 1 polished axe, 1 elongated pebble, 4 miscellaneous objects

plant remains: 1110 items, esp.: wild barley, fig nutlets,

Locus 1003: Fill above house floor

1 pestle legumes

Locus 1004: Fill between house floors

2 bowls, 2 grooved stones, 1 elongated pebble, 2 flaked limestone pieces, 3 hammerstone pounders, 1 flake, 3 miscellaneous objects

plant remains: 608 items, esp.: wild barley, fig nutlets, legumes

Locus 1005: Fill above house floor

1 stone bowl

plant remains: 4966 items, esp.: wild barley, fig nutlets, legumes

plant remains: 1517 items, esp.: wild barley, fig nutlets,

Locus 1006: House floor

1 stone bowl, 1 palette, 1 hammerstone, 3 unidentified fragments legumes

Locus 1007: Disturbed bricky fill

1 pestle, 3 elongated pebbles, 1 hammerstone

plant remains: 303 items, esp.: wild barley, fig nutlets, legumes

plant remains: 4945 items, esp.: wild barley, fig nutlets, legumes, Malva parviflora (seed)

Locus 1013: Fill under house floor

3 pestles, 3 handstones, 3 elongated pebbles, 1 hammerstone

1 hammerstone, 3 unidentified fragments, 1 flake, 1 miscellaneous object Locus 1014: Bricky fill

1 flake

Locus 8: House floor

Small room: 1 cuphole slab, 1 broken vessel

Large room, Cluster 1: 1 cuphole slab, 8 pestles and/or handstones next to it Large room, Cluster 2: 1 cuphole slab, 2 pestles and/or handstones next to it

Large room, Cluster 3: 5 pestles and/or handstone against western wall

plant remains: 339 items, esp.: wild barley, fig nutlets, legumes

plant remains: 3734 items, esp.: wild barley, fig nutlets, legumes

3 adult skull fragments in SE area of large room Sole partitioned house at site

Large room, Cluster 4: ca. 26 items dispersed in middle of room (6 near hearth)

Large room, Cluster 5: 4 items against eastern wall

Locus 50: House floor

1 cuphole slab, 2 pestles, 1 handstone, 1 bowl, 2 axes, 1 palette, 1 pounder, 3 fragments

Locus 27: House floor

2 cuphole slabs, 5 pestles, 3 handstones, 1 vessel, 2 pounders, 3 flakes, 3 miscellaneous

Loci 15-17: outdoor activity area

Cluster 1 (L. 15): 1 cuphole slab, 1 handstone, 2 bowls, 1 perforated item, 1 hammer

Cluster 2 (L. 16, paved area next to hearth): 1 bowl

Cluster 3 (L. 17, hearth): no ground stone tools

\section{Betic Hagdud}

Loci 19 and 23: outdoor activity area (? uncertain)

Locus 19: 1 cuphole slab, 1 bowl, 1 elongated pebble

Locus 23: hearth with pestle in fill

Locus 21: House floor

Subocus A: 1 cuphole, 4 hammerstones

Subocus B: 1 cuphole, 1 pestle, 1 handstone, 1 shaft straightener

Locus 55: House floor

On floor: 2 bowls, 1 overturned, 1 in situ; hearth

From slab-lined pit against wall: 1 handstone, 1 decorated handstone, 3 grinding bowls, 3 shaft straighteners 
stone artefacts show that these tools are more diverse in form than the PPNA versions (Wright 1992; 1993; forthcoming). Large milling tools - grinding slabs and handstones - dominate the PPNB food processing equipment. Many of these are considerably larger than their PPNA counterparts and would have permitted cooks to process more food in a given operation (Figs 8 \& 9). Many grinding slabs were essentially immovable. For example, of 26 complete grinding slabs from Beidha, the mean weight was $26.74 \mathrm{~kg}$; some slabs weighed as much as $52 \mathrm{~kg}$. The handstones used with these slabs vary from small discoidal tools requiring only one hand to operate, to large oval and loaf-shaped handstones demanding the use of two hands and weighing up to $2.50 \mathrm{~kg}$. Other PPNB ground stone tools include small mortars and pestles and limestone pebbles with cupholes (often with carbon residues on the interior and possibly used as lamps).

Vessels, usually made of limestone but sometimes of basalt, are much finer and more diverse in size and shape than those of the PPNA (Fig. 10). They were well made, but simple and normally undecorated (with rare exceptions). Shapes are open forms; closed forms are essentially unknown, as are spouts, handles, lugs, or lids. Vessel rims are either rounded, tapered, or flat; bases are almost always round or flat. Vessel forms include miniature bowls and plates; mediumsized globular bowls and V-shaped bowls with thick walls and flat bases; and rare examples of cups on pedestals. Platters, a PPNB innovation, are the most numerous vessels, especially in the middle and late PPNB. At Beidha, of 73 stone vessels, 34 were platters. They are large and shallow, oval or rectangular in plan, often with thin walls. Ranging in size from $300 \mathrm{~mm}$ to $1.0 \mathrm{~m}$ in diameter, these platters could hold more food at one time than most PPNA bowls. The smaller platters would have been portable; those from Beidha weigh between $5 \mathrm{~kg}$ and $10 \mathrm{~kg}$. A few platters at Beidha had traces of burning on the exterior base and may have been used in cooking (Wright 1992; forthcoming).

Other vessels were made of cordage, basketry (sometimes with waterproof asphalt linings), wood, stone, plaster, and early versions of pottery. Plaster vessels are more complex than stone vessels, with pedestal bases and sometimes, incised and painted designs (Goren \& Goldberg 1991; Rollefson 1990; Rollefson \& Simmons 1984, 21-2; Schick 1988; Wright 1993).
Early and Middle PPNB villages consisted of small rectilinear houses, open areas between them, and special-purpose buildings. The most common house forms were pier houses, named for the piers that divided house space into two or three rooms, resulting in an open, direct-access plan resembling a megaron (Figs $11 \& 12$ ). In the classic pier house, a single house door, sheltered by a porch, led into a small antechamber sometimes partitioned into bins. Directly in line with the front door, a second doorway led into the largest room at the rear, which often held posts and a central hearth. Walls and floors were covered with thick lime plaster, sometimes polished and painted. Normally freestanding, and never larger than $40 \mathrm{~m}^{2}$, pier houses were often built in parallel rows opening onto terraces, courtyards, and alleyways (Byrd \& Banning 1988).

In pier-house villages, houses were open to view by neighbours, as Banning observed (1996), but there are also nuances. These houses have newly elaborate doorways marked by steps, porches, and paved areas marking off the boundaries between the individual house and the rest of the village. Milling stations, firepits, and storage features are concentrated near house entrances or on terraces just beyond them. Inside houses, the largest, most sheltered rooms often have benches, platforms, and plastered hearths with stone linings or raised clay borders, which were sometimes painted.

\section{Munhata}

The PPNB levels at Munhata were damaged by Late Neolithic digging and the stratigraphic sequence is not as secure as one would like. As published, Level 3 has large hearths, unlined firepits, milling toolkits, and vessels clustered on paved and plastered outdoor surfaces near house entrances. The main features inside houses are small, centrally-placed, stone-lined hearths, along with benches (banquettes) (Fig. 11a; Gopher \& Orrelle 1995; Perrot 1966b, 51-2, fig. 1).

\section{Jericho}

Jericho was excavated in long narrow trenches, so that most of what we know concerns individual houses. One classic pier house held storage bins just inside the entry porch and a hearth room at the back of the house. Another house was entered from a narrow lane, up steps into a small anteroom with a curved wall and a hearth just inside the door (Fig. 11b-c) (Kenyon \& Holland 1981). 

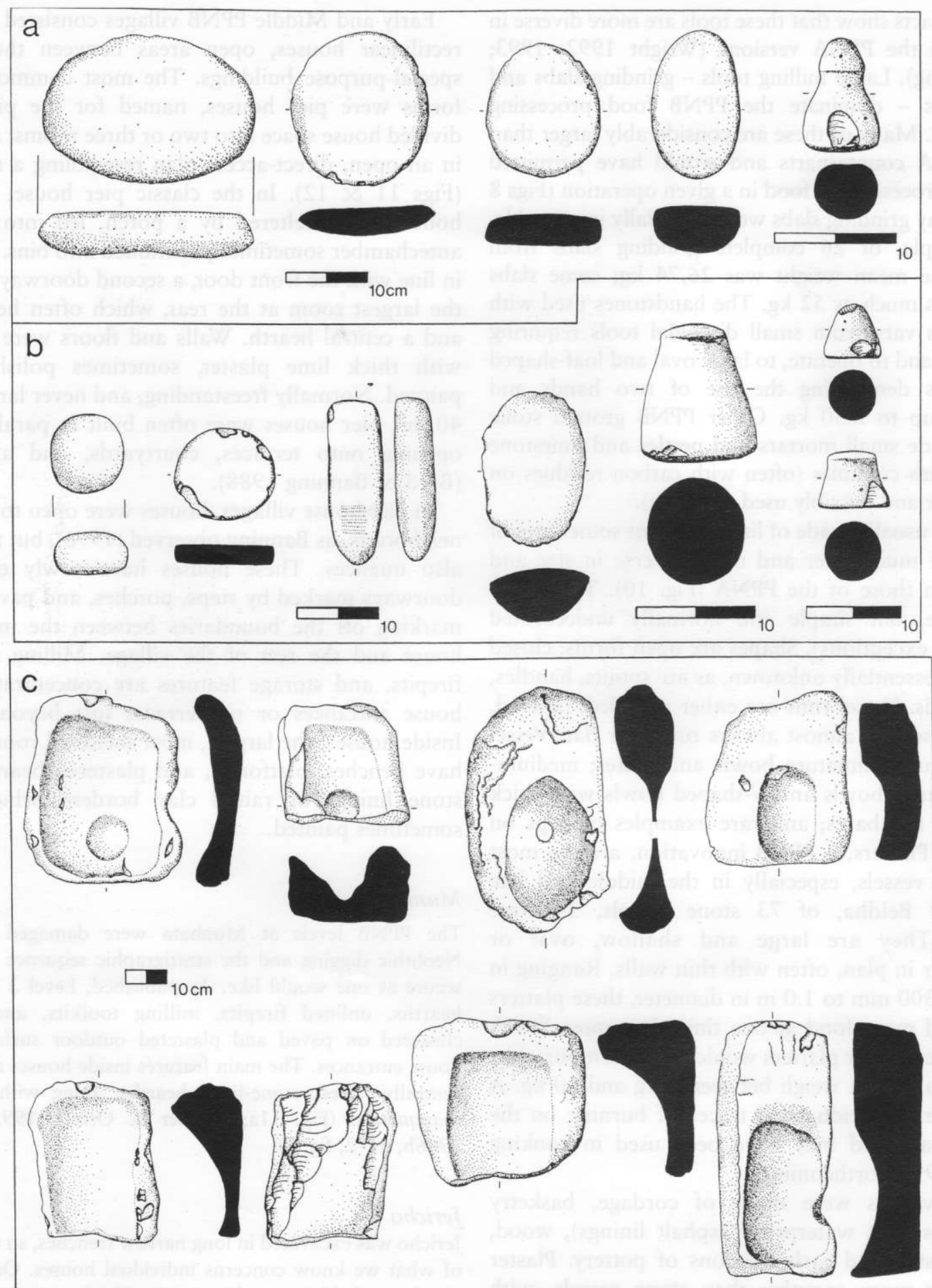

Fig. 8

Pre-Pottery Neolithic B ground stone artefacts. a. small grinding slab, ovate handstones and pestle with handle from Beidha House 49, Phase A; b. handstones and pestles from Beidha House 10, Phase C; c. cuphole slabs and grinding slabs from Beidha (unphased). (From Wright 1992; forthcoming) 
(a)

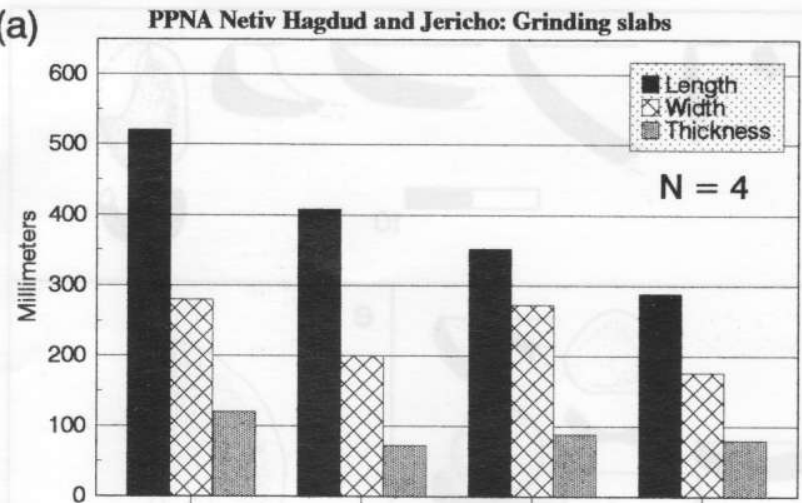

(b)

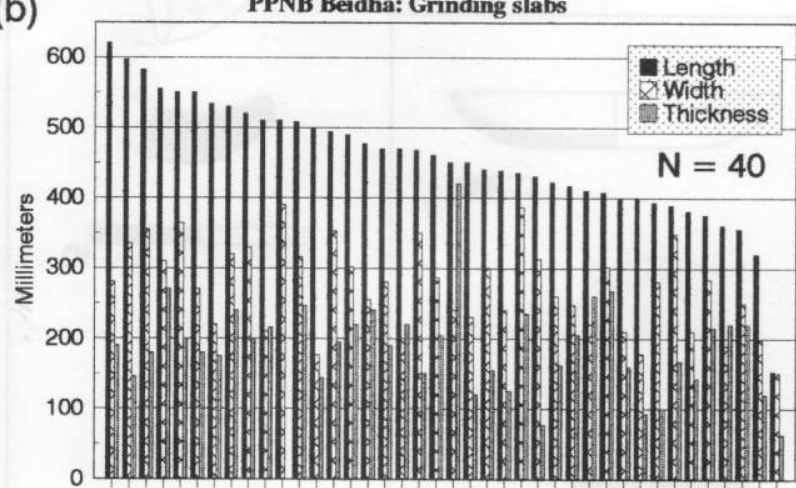

(c)

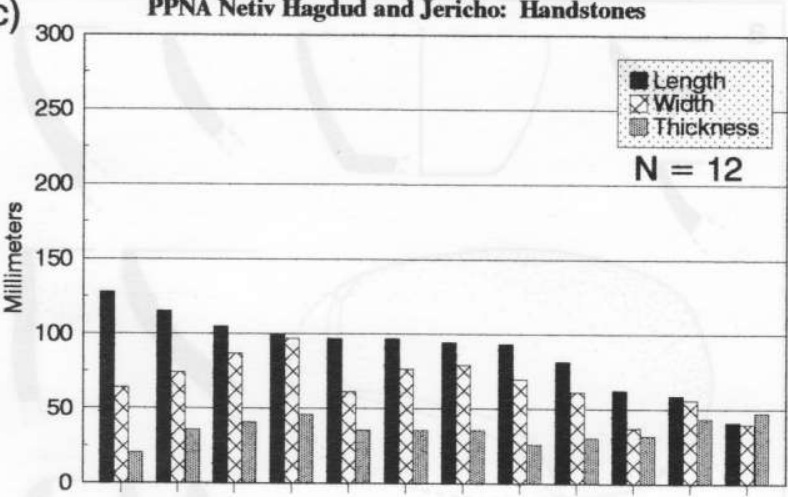

(d)

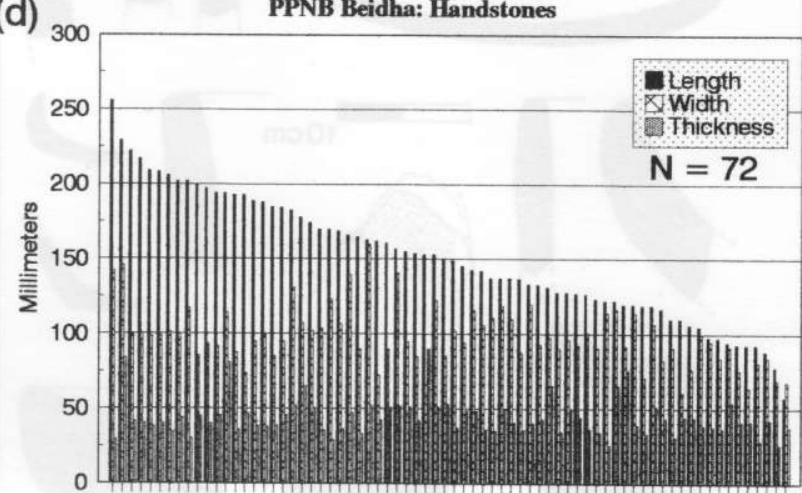

Fig. 9

Comparison of sizes of handstones and grinding slabs from PPNA Netiv Hagdud and Jericho and Early-Middle PPNB Beidha. Each tick on the $\mathrm{x}$-axis represents an individual artefact. All artefacts are complete except where noted.

(After Dorrell 1983; Gopher 1997; Wright forthcoming)

\section{Abu Gosh}

Abu Gosh was excavated over a broad area but the PPNB layers were rather disturbed. Apart from burials, house interiors displayed few features. Hearths and firepits were found only between rows of houses and in a large walled open enclosure (Lechevallier 1978, fig. 4).

\section{Beisamoun}

At Beisamoun 1, all the milling tools from the best preserved house, in this case portable handstones and pestles, were found clustered on the paved entry porch at the house door. Steps and a door led into the single inner room, where the hearth was placed just inside the door. Apart from two postholes, the hearth room was essentially bare (Fig. 12d; Table 4) (Lechevallier 1978, 143-4, fig. 47).

\section{'Ain Ghazal}

At 'Ain Ghazal, Middle PPNB villagers occupied houses built side-by-side in rows, on level terraces dug out of the hillslope. Salvage excavations in the early 1980s exposed partial plans of Middle PPNB pier houses on a terrace damaged by modern road-building (Banning \& Byrd 1987; Kafafi \& Rollefson 1994; 1995; Rollefson 1997 and passim; Rollefson et al. 1990; 1992).

Two adjacent pier houses (Houses 6 and 4) illustrate stages of renovation as a neighbourhood evolved on a terrace (Fig. 12a-c). The houses were built flush with each other on basal clay. House $4 \mathrm{a}$ was built first, with a door to the south, later blocked by the building of House 6a. In phase $b$, we have only the rear portions of the houses, the doors having been destroyed by modern road-building. At this time, the houses were either made smaller or moved to the east, whilst the terrace at the rear was filled with earth, levelled, and expanded in size (Banning \& Byrd 1987, figs $3,4 \mathrm{~b})$.

Eventually, House 4 acquired a porch with two new doors opening onto the terrace, at what had formerly been the rear of the house (phase c). The porch floor was crudely plastered with clay and held a low bench, a small stone bin, 


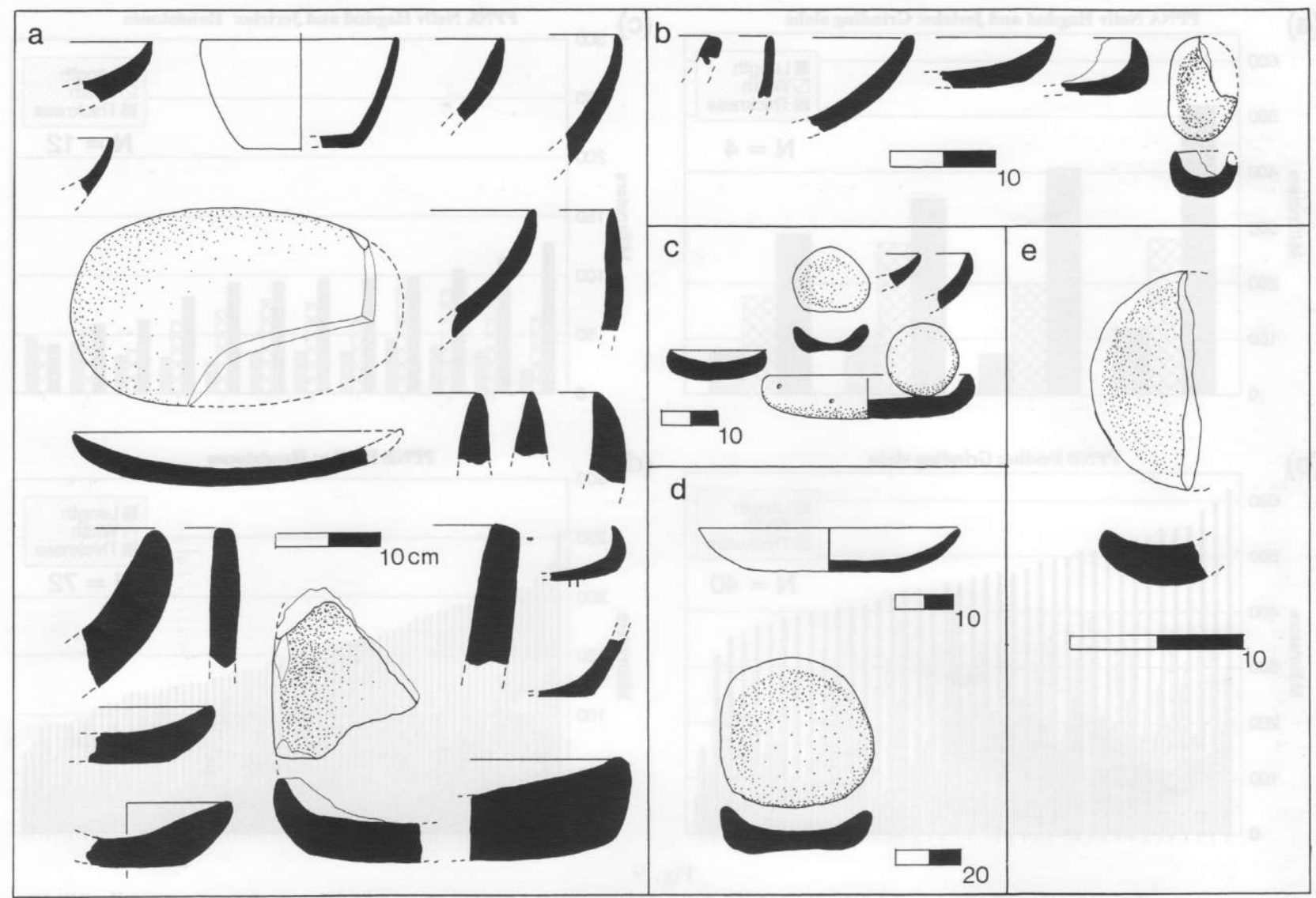

Fig. 10

Pre-Pottery Neolithic B stone vessels from sites in the southern Levant. a. Abu Gosh; b. Beisamoun; c. Munhata; d. Kfar Hahoresh; e. Beidha. Note the absence of decoration and the frequency of large shallow platters. (Redrawn from: a. Lechevallier 1978, fig. 32; b. ibid., fig. 69; c. Perrot 1966b, fig. 5; d. Goring-Morris et al. 1994, fig. 10)

and a group of 11 unbroken, portable discoidal and oval handstones in situ (cf Beisamoun) (Table 4). Complete stationary grinding slabs were not found here and in general were rare on Middle PPNB house floors at 'Ain Ghazal (Wright 1992). Either they were removed for reuse, or milling stations were on the terraces, convenient to largescale cooking facilities. Large stone-lined firepits were found on outdoor terraces at 'Ain Ghazal. These were as deep as $0.25 \mathrm{~m}$ and sometimes contained oak charcoals (Rollefson 1984, 9; 1985, 49; 1990, 40-1; Rollefson \& Simmons 1986, 158).

Stone-lined bins and storage areas were also placed just within or just outside of houses. Thus, House $6 \mathrm{c}$ had a small storage bin at one outer corner. At House 12, large quantities of lentils, peas, and barley were recovered from an unplastered area set off by a curved stone border near a door (Table 4). All of these storage features were very small (Rollefson 1997, 288; Rollefson \& Simmons 1986, fig. 9).
The 'Ain Ghazal houses never exceeded about $40 \mathrm{~m}^{2}$ and most were smaller. The largest, most private rooms (at least half of the roofed space) were hearth rooms. The hearths were shallow, sunken circles, varying from $0.50 \mathrm{~m}$ to $0.90 \mathrm{~m}$ in diameter and almost always placed in the centre of the room. They were the focus of considerable attention and elaboration. Some had raised clay borders around the perimeter; most were repeatedly replastered. Some were painted (in red) around the edge, on the raised border; in one case the entire basin was painted. The hearth fills, composed of fine powdered ash but little charcoal, produced virtually no identifiable archaeo-botanical remains, although plant remains were sometimes recovered from floors near the hearths (eg, House 4c). Hearth rooms were often very clean when excavated, with few in situ artefacts, but in House 12 (phase 2), an oval stone bowl rested on a floor near a wall (Banning \& Byrd 1984, 17-19, fig. 3; Donaldson in Rollefson 1985, 54; Rollefson 1983a, 12; 1990, 40, 44). 


\section{K. Wright SOCIAL ORIGINS OF COOKING \& DINING, EARLY VILLAGES, WESTERN ASIA}

TABLE 4: SELECTED CONTEXTS OF FOOD PROCESSING ARTEFACTS IN PPNB AND LATE NEOLITHIC SITES

Description
Beisamoun Level 1: Middle PPNB (Ref: Lechevallier 1978, 134-44, fig. 47)
Pier house floor (Level 1 House)
House entrance area (porch):
Cluster 1 (Locus 180): next to plastered skull: 1 vessel fragment, 3 handstones, utilised pebble; found
with bone spatulas, projectile points and other lithic tools
Cluster 2 (Locus 185): SE of stone pile, against wall: 3 handstones, 5 bifacial pieces
Cluster 3 (Locus 182): around stone pile: handstones, mullers, perforated weights(?), utilised pebbles;
found with sickle blades, projectile points, burins, scrapers
Hearth room:
Stone-bordered hearth astride house door

Associated finds/comment

House entrance area (porch):

Open anteroom/front porch

Hearth just inside main room at door

Hearth room:

Burial on opposite side of door Post-holes; otherwise quite clean

Ain Ghazal: Middle PPNB (Ref: Rollefson \& Leonard 1983, fig. 1; Banning \& Byrd 1987, 320, fig. 4b; Rollefson \& Simmons 1986b, fig. 9 ) Pier house floor (House 4c, Sq. 3083)

House entrance area (porch):

11 handstones, small discoidal (basalt) and medium oval (quartzite); (1 handstone has ochre stains); sickle blade

\section{Hearth room:}

Plastered central circular hearth

Pier house floor (House 12, Sq. 3073/3273)

House entrance area (porch):

Unplastered area within stone border and thousands of lentils, peas, some barley; possible bin feature

on other side of stone border; area opens onto terrace(?)

Hearth room:

Plastered, painted central circular hearth

Beidha: Early/Middle PPNB (Ref: Byrd 1994; forthcoming; Wright 1992; forthcoming)

Circular house floor (House 49, floor), Phase A1

7 discoidal handstones, 1 oval handstone, 1 elongated handstone, 1 miscellaneous handstone,

1 handstone fragment, 3 ground spheres, 1 conical pestle, 1 irregular pestle, 2 pebble mortars, 2 oval

basins, 1 vessel fragment, 4 ovate celts, 1 weight, 7 hammerstones, 2 polishing pebbles, 2 heavy

elongated hammers

Circular house floor (House 49, floor and fill above it), Phase A1

2 discoidal handstones, 2 oval handstones, 1 ground sphere, 1 cylindrical pestle, 1 pestle with knob

handle, 1 soft miniature pestle, 1 ovate celt, 1 hammerstone, 3 polishing pebbles

Circular house floor (House 60), Phase B

1 miniature axe

Square house floor (House 61), Phase B

1 hammerstone fragment

House entrance area (porch) Curved bench; crude plaster on floor; bin in corner; steps and 2 exits from house

Hearth room:

Burial just south of hearth

House entrance area (porch): Door between this and hearth room was later blocked

Hearth room:

walls and floors of hearth room painted

All but 6 are complete tools

Corridor house (House 5, basement floor and floor fill), Phase C

1 grinding slab, 1 pebble mortar, 2 stone bowls, 1 discoidal handstone, 6 oval handstones, 3 loaf-shaped

handstones, 2 bell-shaped handstone-pestles, 18 hammerstones, 4 polishing pebbles, 1 ovate celt,

2 choppers, 1 pattern-incised pebble

Ain Ghazal: Late PPNB (Ref: Rollefson 1997, 289)

The Terraced House

Basement floor: hearth, oven

Roof collapse above basement floor: oven fragments, lentils, peas

Ba’ja: Late PPNB (Ref: Gebel et al. 1997, fig. 9)

Courtyard compound C: room floors

Court floor, NW corner (Cluster 1): 1 quern, 3 grinding slabs, 13 handstones, 1 weight

1 grinding slab in a fixed mealing bin; hearths in this corner

South room floor, W corner (Cluster 2): 2 grinding slabs, 1 handstone

North room floor, E corner (Cluster 3): 2 grinding slabs, 10 handstones

East room floor corner (Cluster 4): 7 handstones

East room floor corner (Cluster 5): 25 handstones, 1 polishing pebble

East rooms: burnt clay oven fragments in roof collapse 
Basta: Late PPNB (Ref: Nissen et al. 1987, 91-5, fig. 7)

Courtyard compound Area B: room floors

Court floor, centre: oven, clay vessel

Hundreds of grinding stones recovered from fill of structure

Ain Ghazal: PPNC (Ref: Rollefson et al. 1990, 106; Wright 1992)

Corridor house floor cache in corner of rear room (South Field)

1 discoidal handstone, 1 conical pestle fragment, 1 polishing stone, 3 axes

Ain Ghazal: Yarmoukian (Ref: Rollefson et al. 1990, 107, figs 9-10; Wright 1992)

House floor (cache in corner of room) (Yarmoukian House, South Field)

2 handstones, 1 pestle, 2 polishing pebbles, 2 grinding slab fragments, 3 perforated (finished) spindle

whorls, 2 unfinished spindle whorls, 2 perforated irregular stones (loomweights?), 1 bone awl
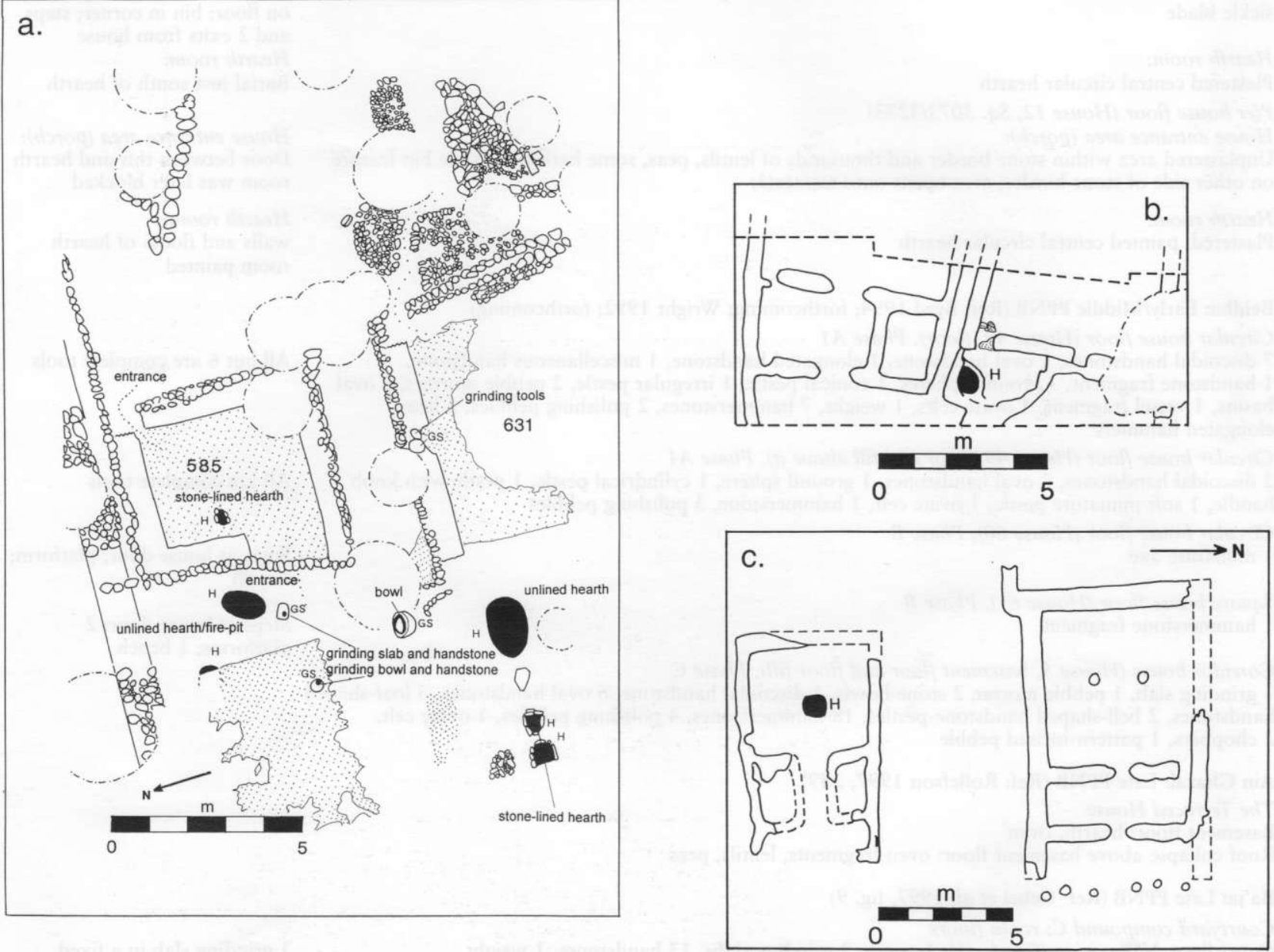

Fig. 11

a. Munhata (Middle PPNB). Key: $\mathrm{H}=$ hearth; GS=ground stone tools or vessels; shaded areas indicate plaster; broken lines indicate pits; b-c. Jericho pier houses (Middle PPNB). Key: $\mathrm{H}=$ hearth; shaded areas indicate steps at doors.

(Redrawn from: a. Perrot 1966b, fig. 1; b-c. Banning \& Byrd 1987, figs 2, 4b; Kenyon \& Holland 1981, pls 263b-c, 286b; Garstang \& Garstang 1948, 59) 


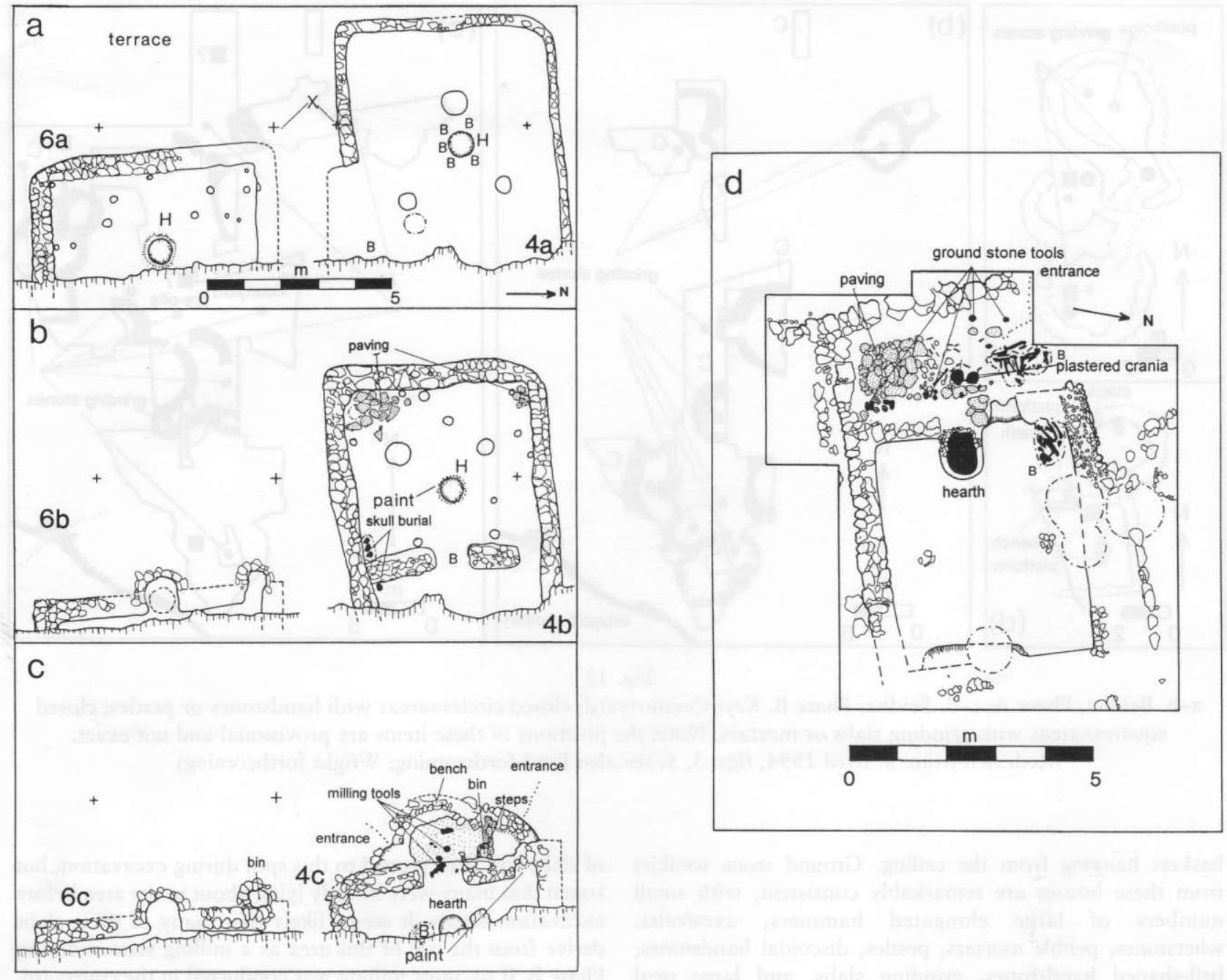

Fig. 12

a-c. 'Ain Ghazal pier houses (Middle PPNB). Two adjacent Middle PPNB pier houses in a terrace row (Houses 4 and 6 ) and three stages of renovation in each $(a, b, c)$. The houses were actually built flush with each other (see point X)

d. Beisamoun pier house (Middle PPNB). Key: $\mathrm{H}=$ hearth; $\mathrm{B}=$ burial or human remains. Shaded areas indicate clay plaster, pavements, or steps. (Redrawn from: a-c. Banning \& Byrd 1987, figs 3, 4b, 5; Rollefson \& Leonard 1983, fig. 1; additional information from Rollefson et al. 1990; d. Lechevallier 1978, fig. 47)

Hearth rooms were one focus of mortuary ritual at 'Ain Ghazal. Decapitated burials, skull caches in pits, and skulls (plastered, painted, or bare) were found under or on the floors in these rooms, frequently near the hearths themselves. In House 4a, five burials were placed in a circle around the hearth, as if to suggest use of the hearth by a small group of people (Rollefson 1985, 54; Rollefson \& \& Simmons 1984, 26; 1986, 153).

\section{Beidha}

Excavated in the 1960s by Diana Kirkbride (1966), Beidha is being re-analysed and published by Brian Byrd (1994; forthcoming). As part of this project, the Beidha ground stone assemblage was studied (Wright 1992; forthcoming). In this large assemblage $(\mathrm{N}=1381)$ it is possible to identify household toolkits and how they relate to other food processing activities.

Houses at Beidha were different in form from those of other Early-Middle PPNB sites. In Phase A (Early PPNB), Beidha was composed of circular one-room houses with multiple doors and open areas between them (Fig. 13a-b). The houses initially had only post-holes but by the end of the phase about half had interior features. One badly burned house held quantities of pistachio probably stored in 


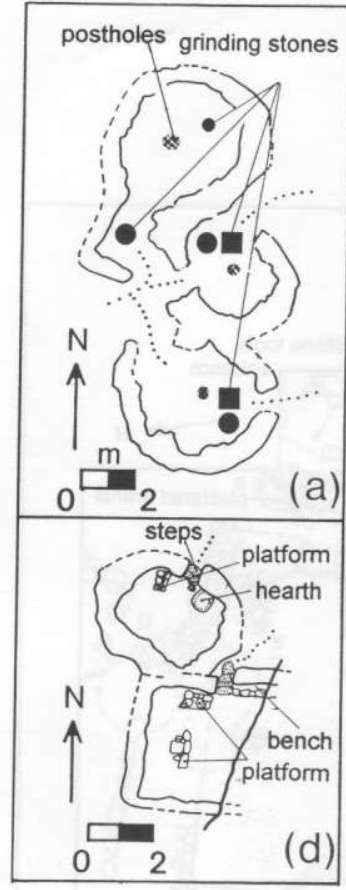

(d)
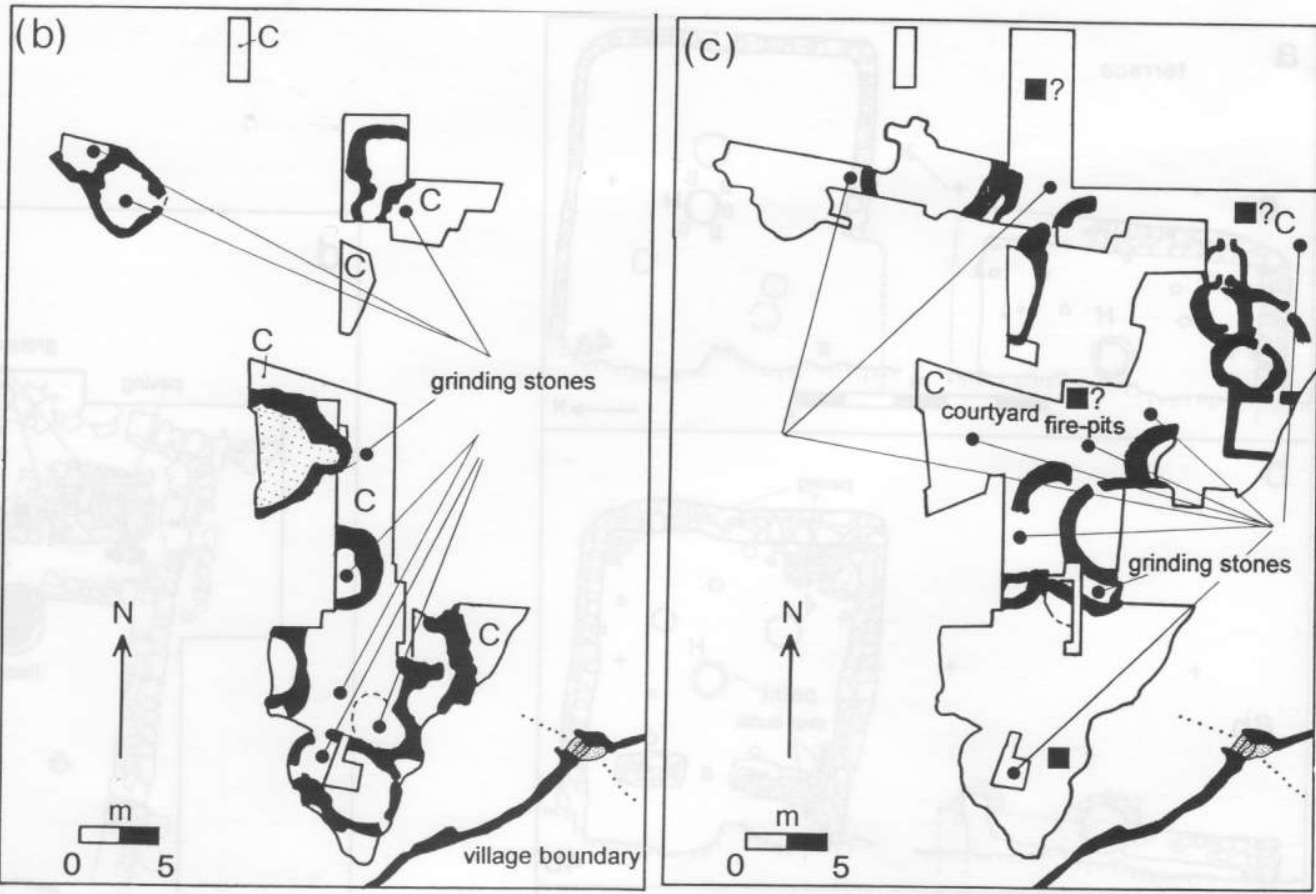

Fig. 13

a-b. Beidha, Phase A; c-d. Beidha, Phase B. Key: C=courtyard; closed circles=areas with handstones or pestles; closed squares=areas with grinding slabs or mortars. Note: the positions of these items are provisional and not exact.

(Redrawn from: a. Byrd 1994, figs. 3, 5; see also Byrd forthcoming; Wright forthcoming)

baskets hanging from the ceiling. Ground stone toolkits from these houses are remarkably consistent, with small numbers of large elongated hammers, axes/celts, whetstones, pebble mortars, pestles, discoidal handstones, bell-shaped handstones, grinding slabs, and large oval basins set into floors (Table 4). Missing from these kits were platters or other portable stone vessels, which were altogether rare before Phase C. In all, the Phase A spatial patterns are similar to those of the PPNA, though the artefacts themselves are different (Byrd 1994; Helbaek in Kirkbride 1966, 63; Wright forthcoming).

In Phase B (Middle PPNB), the houses had hearths, platforms, and benches, but very few in situ artefacts of any kind (Fig. 13c-d). Of the few ground stone tools in these houses, most were axes and hammerstones. In situ grinding slabs, vessels, and mortars were almost entirely absent from Phase B house interiors (Table 4).

In this period, the courtyards were more formally bounded by structures. In the courts, large ashy areas with firecracked stone testify to outdoor cooking (Byrd 1994, 651 , fig. 6). When the study of the Beidha milling tools began in 1988, many large, heavy grinding slabs were found in a large outdoor cluster on one side of the village. Diana Kirkbride (pers. comm., 1989) acknowledged that a number of slabs had been moved to this spot during excavation, but stated that many were already lying about in the area before excavation began. It seems likely that many of these slabs derive from the use of this area as a milling station during Phase B. If so, most milling was conducted in the courtyard, whilst interior platforms, benches and hearths suggest that small groups of people consumed food inside the houses.

\section{Discussion}

Early-Middle PPNB sites display new aesthetics and social rules governing food-sharing. One of the most striking features is the new diversity of vessels made of stone and other materials. The diversity implies an element of specialisation in the practical functions of vessels and more diverse rules of etiquette in using them.

At house doors, steps, porches, paved areas, and benches marked off a transitional zone between house and community. Facilities for storage, milling, and large-scale cooking were often placed in this transitional zone. Persons entering a house would pass directly through milling and cooking stations either in 
community space (terraces, courtyards, alleys) or in transitional 'kitchen-porches' leading into houses. These arrangements were, of course, practical: largescale cooking and milling in front of houses would make it easier to keep house interiors clean, a habit which PPNB villagers obviously valued. But the arrangements also had social implications. Storage and food preparation were highly visible activities which would have posed opportunities for social contacts between household and village, even as individual households seem to have controlled their own processing and storage. It seems likely that households shared some facilities such as immovable grinding slabs and large firepits, and that milling and cooking were conducted by work groups.

Hearth rooms were the most secluded spaces in these houses. They were usually very clean and it is possible that when houses were abandoned, in situ artefacts were carefully removed (and burials put in) as part of a house-closing ritual. Consequently, the role of these rooms in food preparation is difficult to assess. However, several lines of evidence suggest that they were the focus of household meals (at least in winter or in bad weather). First, benches and platforms are characteristic of these rooms. Second, the hearths were carefully decorated, repeatedly replastered and refurbished. They were shallow, and the fills within them imply that they held only small fires. Third, arrangements of burials near or even around the hearths suggest how they were used. Finally, rare bowls and botanical remains found in hearth rooms escaped PPNB house-cleaning and suggest that these rooms sheltered meals. If so, the number of participants would have been small, since the rooms never exceed about $25 \mathrm{~m}^{2}$.

Meals, and the artefacts used in them, are a central means by which social groups educate and enculturate individuals, particularly the young, in proper social behaviour (David et al. 1988). They are also a focus for hospitality. Correct ways of consuming and sharing food in various social contexts are carefully defined and watchfully observed. The rules of consumption vary according to the social situation and cultural perceptions of proper attitudes toward food. If the above reconstruction is correct, mealtimes in PPNB houses were relatively private household affairs and enculturation of this kind was at the household level.

If so, what kind of social grouping occupied these houses? Since residents of a house need not conform to kin units, we cannot be sure. However, house sizes, burials, and anthropomorphic art suggest that the nuclear family and the lineage were central to PPNB social organisation and that age was an important criterion of the social persona of an individual.

Anthropomorphic art in the PPNB betrays a distinct interest in defining stages of maturity for both sexes. Most female figurines (or those identified as such) have developed breasts and often indicate pregnancy. Masks from Nahal Hemar and a plaster statue from Jericho display painted beards on the chins. The 'Ain Ghazal plaster statues, deliberately buried in groups suggesting families or lineages, are portraits of younger and older individuals. Some have carefully delineated cleft, and therefore beardless, chins (Bar-Yosef \& Alon 1988, pl. 10; Kenyon 1979, pl. 14b; Rollefson 1983b, pl. ii, 3).

Like other PPNB art, detachment and decoration of plastered skulls do not correlate with gender, but do correlate with age; only adults received this treatment. Most decapitated burials and detached plastered skulls seem to come from hearth rooms, often near hearths themselves. These burials may not have been immediately visible to house inhabitants at the time of occupation; the burials themelves may have been placed in each house when it was abandoned. However, it is difficult to imagine that householders were unaware of the existence of burials beneath them, since houses were repeatedly built on top of each other.

Some decorated skulls have been found sitting on top of hearth room floors. We do not know whether they were on display while the houses were in use, but if they were, they would have been reminders of traditional authority represented by lineage forebears, especially adults, to encourage socialisation within the household and respect for elders in lineages, where status was achieved and largely based on age. Children and younger family members may have been the target audience for much Neolithic art, to encourage socialisation into household and lineage traditions (cf David et al. 1988). Age-set relations - elders and young - within households may have been the most crucial power relations, perhaps the mechanism par excellence of new forms of social control in early permanent villages. Surprisingly little attention has been devoted to age-grade relationships in prehistoric studies, despite a vast literature on their importance in small-scale societies today (eg, Mead 1928; Willson 1949).

If the foregoing analysis is correct, food preparation was an arena for social interaction 
between households, whilst meal consumption seems to be about privacy, the residential group, and enculturation within the lineage. If so, these habits may reflect tensions between new forms of community cooperation and traditional kinship organisation.

\section{PANTRIES AND PRIVATE PROPERTY: LATE PRE-POTTERY} NEOLITHIC B, c. 7550-6850 cal BC

In the Late PPNB, some villages grew to unprecedented sizes of 12-15 ha. Houses, often with two stories and complex plans, were as much as four times larger than those of the Early PPNB, up to 160 $\mathrm{m}^{2}$ (Rollefson 1997). We also see larger milling tool assemblages per house and more specialised cooking facilities such as ovens, fixed mealing bins, plaster vessels, experiments with pottery-making. Food preparation within houses is more secluded, sometimes in specialised rooms (kitchens). Storage facilities become larger and more elaborate, to include whole rooms. In all, these changes testify to intensified production of prepared foods. It seems likely that sheep and goat domestication was part of this general

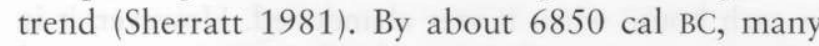
(but not all) PPNB villages were abandoned. Population growth, the scale of house-building, tree felling, farming, and early herding may have all contributed to this disruption by causing local environmental damage around individual sites (Rollefson \& Kohler-Rollefson 1989).

\section{Beidha}

In Phase C, transitional to the Late PPNB, Beidha evolved into a dense village of two-storey corridor buildings opening onto bounded courtyards. Beidha's seem to be the earliest corridor buildings in the southern Levant. Each corridor building consisted of a basement with up to six small niches $\left(1 \mathrm{~m}^{2}\right)$ linked by a central narrow corridor reached by $2-3$ steps down from the house door (Fig. 14a). Some of the niches had partition walls closing them off, forming secure, private cupboards. The second storeys almost certainly had pier house plans. In this phase, distinctions between private and public space became sharper. Access to houses was steered by definite paths. Houses were less open, with only one door and steps marking household-community boundaries. The main courtyard was enclosed and seemingly few activities were conducted in it. Large firepits and hearths occurred just outside the village, but many activities moved 'in-house' (Byrd 1994, 655).
Nearly all evidence for food preparation and consumption comes from within houses in Phase C (Wright forthcoming). The numbers and diversity of ground stone tools from inside houses were much greater and more variable from house to house. One or two houses yielded many such items and others very few. In house basements, niches held caches of handstones, pestles, mortars, globular bowls, platters, and axes (Table 4). Immovable slabs, many heavily worn, were placed in basement floors, typically in the corridor near the house entrance. Handstones from this phase were diverse in size and form. Many were very large handstones requiring two hands to push across a slab.

Hearth fragments were found in collapse and fill from the upper floors, the probable centres of cooking and dining. Stone vessels, which first appear in significant numbers in Phase C, support this interpretation. Of 37 vessels or vessel fragments, most came from contexts within houses. In contrast to the grinding slabs and handstones, most vessels (33 of 37) were broken. Most also came from fills resulting from the collapse of the upper floors, where they were probably used.

\section{Ain Ghazal}

At $12-15$ ha, Late PPNB 'Ain Ghazal is one of the largest Neolithic sites in the Middle East. Houses were larger and more variable in plan, with division of interior spaces into smaller rooms. Some villagers occupied small apsidal houses, rectangular with one curved wall. Others occupied large, two-storey corridor buildings attesting to the growth of residential units (Rollefson 1997, 292). One of these, the Terraced House, had a hearth and an oven in the basement corridor, in a position that could not be readily seen from the house door (Fig. 14b). The Terraced House basement corridor was small, implying that the space was mainly dedicated to cooking, with convenient access to storage niches. Collapse and fill from the upper floor produced masses of legumes and clay oven fragments, suggesting that the upper floor held additional facilities for storage, cooking, or consumption (Table 4; Kafafi \& Rollefson 1994, 240).

\section{Basta, es-Safiya, 'Ain el Jammam}

In southern Jordan, Basta is a 12 ha village with large courtyard houses as much as $160 \mathrm{~m}^{2}$ in size. The Area B complex was composed of a large roofed court surrounded by small rooms on four sides. Over 2000 ground stone artefacts were recovered from Basta in two seasons of excavation, hundreds from the Area B building alone (Table 4). They included large (two-handed) handstones, large grinding slabs, stone vessels, and other items (Qadi in Nissen et al. 1987; Qadi pers. comm.). Many were found in fill and used in rebuiding, so activity areas have not been identified, but an oven was discovered in the central room 
10. K. Wright SOCIAL ORIGINS OF COOKING \& DINING, EARLY VILLAGES, WESTERN ASIA
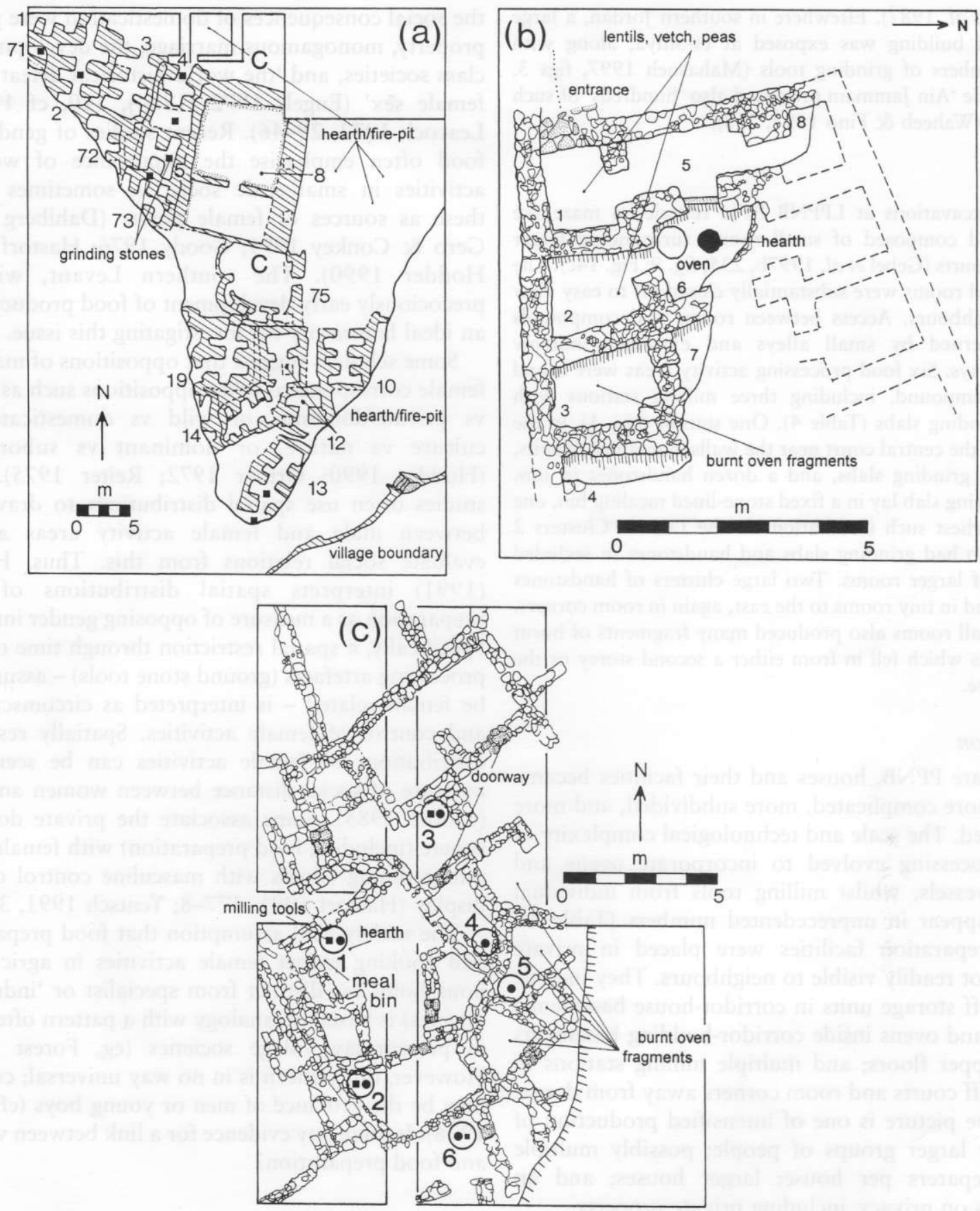

Fig. 14

a. Beidha, Phase C (Middle-?Late PPNB). Phase C corridor buildings with basements (shown) and upper floors. Closed squares indicate areas with grinding slabs or fragments thereof. Note: the positions of these items are provisional, and not exact; b. 'Ain Ghazal, the Terraced House (Late PPNB); c. Ba'ja (Late PPNB); Milling stations and caches of milling tools. Heavy grinding slabs (squares) and large handstones (circles) were found in Clusters 1, 2, 3 and 6; Cluster 1 also had a fixed mealing bin and other features. Large caches of handstones were found in Clusters 4 and 5 . The burnt clay oven fragments probably fell into the small rooms from above. (Redrawn from: a. Byrd 1994, fig. 7; additional data from Byrd forthcoming, Wright forthcoming; b. Rollefson 1997, fig. 3; c. Gebel et al. 1997b, figs 1 and 9) 
(Nissen et al. 1987). Elsewhere in southern Jordan, a large courtyard building was exposed at es-Sifiya, along with large numbers of grinding tools (Mahasneh 1997, figs 3, 6-7), while 'Ain Jammam produced also 'hundreds' of such artefacts (Waheeb \& Fino 1997, 218).

\section{$B a^{\prime} j a$}

Recent excavations at LPPNB Ba'ja revealed a maze-like compound composed of small rooms surrounding larger interior courts (Gebel et al. 1997b, 235, fig. 9; Fig. 14c). The courts and rooms were substantially closed off to easy view from neighbours. Access between rooms and compounds was governed by small alleys and extremely narrow passageways. Six food processing activity areas were found in the compound, including three milling stations with heavy grinding slabs (Table 4). One station (No. 1), in the corner of the central court near the walls, contained firepits, five large grinding slabs, and a dozen handstones in situ. One grinding slab lay in a fixed stone-lined mealing bin, one of the earliest such installations in the Levant. Clusters 2 and 3 also had grinding slabs and handstones in secluded corners of larger rooms. Two large clusters of handstones were found in tiny rooms to the east, again in room corners. These small rooms also produced many fragments of burnt clay ovens which fell in from either a second storey or the roof above.

\section{Discussion}

In the Late PPNB, houses and their facilities became larger, more complicated, more subdivided, and more specialised. The scale and technological complexity of food processing evolved to incorporate ovens and plaster vessels, whilst milling tools from individual houses appear in unprecedented numbers (Table 4). Food preparation facilities were placed in private spaces not readily visible to neighbours. They include walled-off storage units in corridor-house basements; hearths and ovens inside corridor-building basements or on upper floors; and multiple milling stations in walled-off courts and room corners away from doors. In all, the picture is one of intensified production of food for larger groups of people; possibly multiple food preparers per house; larger houses; and an emphasis on privacy, including private property.

\section{WOMEN, MEN AND FOOD PREPARATION}

That the emergence of food production heralded changes in the sexual division of labour has been long suspected. In the 19th century, it was proposed that the social consequences of domestication were private property, monogamous marriage, the development of class societies, and 'the world historical defeat of the female sex' (Engels 1972 [1884], 120, cf 117-19; Leacock 1972, 29-46). Recent studies of gender and food often emphasise the importance of women's activities in small-scale societies, sometimes seeing these as sources of female power (Dahlberg 1981; Gero \& Conkey 1991; Goody 1976; Hastorf 1998; Hodder 1990). The southern Levant, with its precociously early development of food production, is an ideal laboratory for investigating this issue.

Some scholars suggest that oppositions of male and female correspond to other oppositions such as public vs private/domestic, or wild vs domesticated, or culture vs nature, or dominant vs subordinate (Hodder 1990; Ortner 1972; Reiter 1975). Such studies often use spatial distributions to draw lines between male and female activity areas and to evaluate social relations from this. Thus, Hastorf (1991) interprets spatial distributions of food preparation as a measure of opposing gender interests. Specifically, a spatial restriction through time of food processing artefacts (ground stone tools) - assumed to be female-related - is interpreted as circumscription and control of female activities. Spatially restricted distributions of female activities can be seen as a measure of social distance between women and men (Moore 1985). Some associate the private domestic sphere (including food preparation) with females, and public dining rituals with masculine control of elite display (Hastorf 1991, 477-8; Yentsch 1991, 319).

The widely-held assumption that food preparation and cooking reflect female activities in agricultural households (as distinct from specialist or 'industrial' settings) is based on analogy with a pattern often seen in present-day village societies (eg, Forest 1996). However, this pattern is in no way universal; cooking may be the province of men or young boys (cf Mead 1928). Is there any evidence for a link between women and food preparation?

\section{Osteological Evidence}

Osteological evidence from sexable skeletons, which might be expected to inform on this question most directly, presents a complicated picture and in any case may always be equivocal. On the basis of tiny samples, Molleson stated that at Epipalaeolithic (cf Natufian) Abu Hureyra, pathologies in metatarso- 
phalanges and arm and shoulder joints were specific to females and resulted from habitual kneeling in the use of saddle querns (Molleson 1989, 357f.; 1994). In a more comprehensive analysis of stress lesions and robusticity in 106 Natufian and Neolithic male and female skeletons, Peterson $(1994 ; 1997)$ found more sexual dimorphism in functional-stress variables in the Natufian - which could be explained by food preparation - than in the Neolithic, when male and female patterns converge and both display indications of increased physical workloads. On the other hand, she also notes evidence consistent with an interpretation that males were more active in tree felling and tilling in the Neolithic and that investigations of degenerative joint disease and trauma are necessary to evaluate gender-related tasks (Peterson 1997, 488). Miller's $(1982,210)$ study of large skeletal samples from Chavez Pass in the American South-west found abnormally high incidence of degenerative joint disease in the elbows of adult females, attibuted to 'high stress loadings on the articular cartilage of the elbow joint ... [from] ... grinding with a mano and metate.' No such pattern has so far been identified in south-west Asia.

\section{Artefacts}

Two other lines of evidence, though indirect, may permit us to establish a link between women and food preparation. A cache of ground stone tools was found on the floor in the corner of a Late Neolithic (Yarmoukian) house at 'Ain Ghazal. The cache contained two grinding slab fragments, four handstones, one pestle (milling); and three perforated spindle whorls, two disks (=unfinished spindle whorls), two irregular perforated stones (loomweights), and a bone awl (weaving) (Rollefson et al. 1990, figs 9-10; Wright 1992). Thus, the cache contains toolkits for milling and weaving.

\section{Early Historical Evidence}

Texts and seals from early historic Mesopotamia support a link between weaving, milling, and adult women. Thus, archives of private business estates specialising in milling are known from the 3rd millennium BC. Both male and female millers are mentioned but women far outnumber men (CAD arraru, arraratu, bit arrari; Damerow 1996, 153; Foster 1982, 11-13; Harris 1975, 270-2; Schneider 1926). Links between adult women and weaving in estates are also documented in the 3rd millennium (Maekawa 1980). In Mesopotamian private households of the 2nd millennium $\mathrm{BC}$, dowry items include handstones (CAD s.v. narkabu). In a legal text, a man accused of theft states: 'I swear, I did not take any property of my sister, neither her millstone ... nor anything else' (NA4 HAR; Salonen 1966, 51). Millstones were received by women as gifts from their husbands and the tools were considered the women's property; other women received millstones from their fathers and as bridal gifts (Harris 1975, 319, 330, 369). A private letter alludes to a creditor seizing the wife and daughter of a man in debt and putting them to work milling barley (Oppenheim 1967, 91).

\section{The PPNB}

If we assume that adult women dominated milling and cooking in the Neolithic, it follows that in the Middle PPNB they were conducting these activities very much in the open, on kitchen-porches or just beyond, at the boundary between household and neighbour. In the Late PPNB, when both houses and sites grew larger, milling and cooking facilities were placed in much more restricted spaces and testify to the retreat of these activities into the private domestic domain. If adult women were primarily responsible for these activities, they conducted them in confined, relatively hidden spaces.

Some ethnoarchaeological studies of agricultural villages have found correlations between the number of economically active women in a household and the number of grinding slabs (or sets of $2-3$ slabs) in the house (Hayden \& Cannon 1984, 68-74; cf Kramer 1982, 33-5). Assuming that multiple milling stations of Late PPNB houses (as at Ba'ja) were in use at the same time, there may have been more economicallyactive women per house than in the Middle PPNB.

\section{CORPORATE GROUPS: SPECIAL BUILDINGS AND SPECIAL SITES}

Rollefson and Kohler-Rollefson (1989) have made a compelling case for intensive exploitation of local environments in the Late PPNB. Food preparation seems to fit this general picture. The sheer numbers of milling tools from individual houses, combined with new technologies such as ovens and plaster vessels, all point to intensification of labour in preparing food for 
larger numbers of consumers. But who were they? Was it simply a matter of larger households and growing populations? Or were there external pressures to produce more, coming from other households, or from wider social institutions?

Many PPNB villages have large buildings of unusual plan. Banning (1996) interprets these as possible evidence for ostentatious hospitality. At Beidha, two large, unusual buildings of Phase C (Buildings 8 and 75) are interpreted as public structures for corporate institutions that integrated the village (Byrd 1994). Building 8 (the Square Building, actually a large pier house) could accommodate more people at one time than any other roofed space in Phase C. Its contents were a large circular hearth, a polished limestone slab, and floor paint (Byrd 1994, in prep.; Kirkbride 1966, 13; Wright forthcoming). Building 75 is circular and may be a storage building. On the whole, the functions of these buildings are ambiguous. But one thing is clear: in sharp contrast to the corridor houses, these buildings were devoid of milling tools. Much the same seems to be true of special buildings at other sites.

Special-purpose sites, which also lack milling tools, hint at one type of corporate group in the PPNB.

\section{Nahal Hemar}

Nahal Hemar Cave is a non-habitation site which produced a hoard of special items in association with a number of juvenile and adult skulls. All of the adult skulls appear to be male (Bar-Yosef \& Alon 1988; Yakar \& Hershkovitz 1988). One skull, of a man about 50 years in age, was decorated with a hairnet modelled in asphalt and an actual matching textile hairnet was also found. Cultivated cereals and legumes and asphalt-lined baskets were recovered but no ground stone tools were recovered. The hoard contained projectile points, textiles, figurines of human heads, beads, plaster items, and stone masks, one with a painted beard. A sourcing study by Goren et al. (1993) showed that plaster artefacts from Nahal Hemar were made in more than one place, suggesting that a number of villages participated in the use of these items. In all, the site suggests corporate ritual activities involving men; and roles or statuses marked by beardedness and special headdress.

\section{Dhuweila}

Late PPNB Dhuweila in the Jordanian desert, interpreted by the excavator as a hunting camp, produced a few very crude ground stone artefacts (mostly cobbles used in an ad hoc way for grinding; Betts 1998; Wright 1998). A flagstone from a structure was carved with a scene showing groups of hunters holding bows, with varying headdresses (Betts 1998, fig. 7.1).

\section{Discussion}

Quite apart from special sites, images of male corporate groups engaged in real or ritualised hunting are widespread in art from Neolithic villages across the Near East. These works date to the PPNB and the early ceramic Neolithic, after which these images seem to disappear from the record. The art shows hunters with great variations of dress, especially headdress. In eastern Turkey, adult males, wild animals, and virility are shown in ithyphallic sculptures of men, birds and lions from Early-Middle PPNB Göbeklitepe, a remote site with cultic buildings and no normal houses (Schmidt 1995; 1997; 1998). Special buildings at Nevali Çori contained stelae and sculptures similar to those of Göbeklitepe (Hauptmann 1993). Wall paintings from Çatalhöyük show large mammals and groups of men holding bows, wearing variable headdresses and engaging in either hunting or a mockery of it (Mellaart 1966, pls liv-lix). At Umm Dabaghiyah, one of the earliest ceramic Neolithic sites in Mesopotamia, massive multi-cellular structures suggesting storage dominate the architecture. Wall paintings showing wild animals were found in this site. Faunal remains dominated by wild animals, especially onager, were found in the cells (Kirkbride 1975).

From these data, I suggest that adult male sodalities involved in real or ritual hunting constituted an important social institution in Neolithic societies, integrating regional groups, transcending and cross cutting individual villages and kinship. These groups may have been acquiring relatively exotic natural resources - unusual wild animals for conspicuous consumption and display. Conspicuous display of these animals appears to be linked to an ideology emphasising men in groups, virility, domination, and initiation of young men into adulthood. Some of these displays were set up in domestic contexts and would have been visible on a daily basis to all household members. Variations in headdress and clothing suggest that different ranks were recognised within these groups. In addition, these groups may have been capable of acquiring surpluses and storing them. If so, such sodalities may have been central to the emergence of complex social hierarchies (Tiger 1970). 


\section{K. Wright SOCIAL ORIGINS OF COOKING \& DINING, EARLY VILLAGES, WESTERN ASIA}

\section{CONCLUSIONS}

Food-related activity areas in the Natufian and PPNA were relatively unspecialised and boundaries between house and communal space seem to have been fluid and unstructured. In the Early and Middle PPNB, we see much more structured spatial rules for food preparation. Milling, cooking, and storage seem to have taken place in areas near house entrances, a border zone between community space and the individual household. These were highly visible, public activities that posed opportunities for social contacts between households. If women were normally in charge of these activities, they were conducting them in an open social setting. Still, individual households seem to have controlled their own preparation and storage facilities and meal consumption may have been centred on the residential group. In the Late PPNB, intensification and 'privatisation' of milling, cooking, storage, and dining seem to have taken place. These activities were more secluded vis-à-vis the village as a whole. If adult women were the primary producers of prepared food, the evidence suggests that they worked in relatively cloistered settings in the Late PPNB.

The patterns discussed here did not persist after the PPNB. Sharp changes in domestic arrangements occurred in the Pre-Pottery Neolithic C and the Late Neolithic, a subject I will deal with elsewhere. Similarly, domestic arrangements for cooking and dining in the Neolithic varied considerably between regions and cultures. Some Anatolian villages display patterns with points of comparison to those of the southern Levant (eg, Hacilar VI; Mellaart 1970), but very different patterns seem to have prevailed at Aşiklihöyük and Çatalhöyük (Esin et al. 1991; Hodder 1997; Mellaart 1966).

In particular, Neolithic populations in greater Mesopotamia had distinct regional food customs. The most elaborate (and widely traded) early ceramics are Mesopotamian. From an early date, Mesopotamian villages had larger, more complex houses sometimes arranged in courtyard compounds, probably implying different forms of social organisation based on larger residential groups (Banning 1996). In these villages we see an emphasis on larger storage systems of diverse types (circular bins, small cell-rooms in houses, whole buildings of multi-cellular cubicles). In Mesopotamia, a high cultural value placed on large-scale storage probably played a key role in surplus production and the eventual large scale and precocious emergence of urban societies there.

After a century of research on agricultural origins we still know very little about many social and cultural aspects of early food production. Spatial analysis of how villagers converted harvests into meals may be a useful route of investigating the impact of early farming on social organisation - and vice versa. Cultural variations in food customs may have had significant long-term effects on surplus production and historical change. Although natural environments, primary production, and agricultural economics at the regional level have dominated discussions of early farming societies, the excavated evidence may tell us as much or more about social environments, consumption, and home economics in those societies.

Acknowledgements: The research project described here was sponsored by the Fulbright-Hays Doctoral Dissertation Fellowship, the British Institute at Amman for Archaeology and History, the American Centre of Oriental Research (Amman), and Yale University Department of Anthropology. For their generous permission to study ground stone assemblages from Natufian and Neolithic sites, and for unpublished data from 'Ain Mallaha, I am profoundly grateful to Ofer Bar-Yosef (Hayonim), Alison Betts (Dhuweila), Brian Byrd (Beidha), Genevieve Dollfus ('Ain Mallaha, Abu Hamid), Philip Edwards (Wadi Hammeh 27), Andrew Garrard (Azraq), Hans-Georg Gebel (Ba'ja), Zeidan Kafafi ('Ain Ghazal, Abu Hamid), Diana Kirkbride (Beidha), Jean Perrot ('Ain Mallaha), Nabil Qadi (Basta), Gary Rollefson ("Ain Ghazal) and Francois Valla (Hayonim). For helpful discussions of the issues and/or criticisms of early drafts, I am grateful to all of the aforementioned, as well as E.B. Banning, Susan Colledge, James Conolly, Louise Martin, Mark Nesbitt, Delwen Samnel, Stephen Shennan, and Peter Ucko. However, responsibility for any errors of fact or interpretation rests with me alone.

\section{BIBLIOGRAPHY}

Appadurai, A. 1981. Gastropolitics in Hindu South Asia. American Ethnologist 8, 494-511

Banning, E.B. 1996. Houses, compounds and mansions in the prehistoric Near East. In G. Coupland \& E.B. Banning (eds), People Who Lived in Big Houses, 165-85. Madison, Wisconsin: Prehistory Press

Banning, E.B. \& Byrd, B. 1984. The architecture of PPNB 'Ain Ghazal, Jordan. Bulletin of the American Schools of Oriental Research 25, 15-20

Banning, E.B. \& Byrd, B. 1987. Houses and the changing residential unit: domestic architecture at PPNB 'Ain Ghazal. Proceedings of the Prehistoric Society 53, 309-25 
Bar-Yosef, O. 1986. The walls of Jericho: an alternative interpretation. Current Anthropology 27, 157-62

Bar-Yosef, O. 1991. The archaeology of the Natufian layer at Hayonim Cave. In Bar-Yosef \& Valla 1991, 81-92

Bar-Yosef, O. \& Alon, D. 1988. Nahal Hemar Cave. Jerusalem: Atiqot 18, Israel Department of Antiquities

Bar-Yosef, O. \& Belfer-Cohen, A. 1991. From sedentary hunter-gatherers to territorial farmers in the Levant. In S. Gregg (ed.), Between Bands and States, 181-202. Carbondale, Illinois: Center for Archaeological Investigations

Bar-Yosef, O. \& Gopher, A. 1997. An Early Neolithic Village in the Jordan Valley. Cambridge, Massachusetts: American School of Prehistoric Research Bulletin 43, Peabody Museum, Harvard University

Bar-Yosef, O. \& Valla, F. 1991. The Natufian Culture in the Levant. Ann Arbor, Michigan: Prehistory Press

Belfer-Cohen, A. 1988. The Natufian graveyard in Hayonim Cave. Paléorient 14 (2), 297-308

Belfer-Cohen, A. 1991. Art items from layer B, Hayonim Cave. In Bar-Yosef \& Valla 1991, 569-88

Betts, A. 1998. The Harra and the Hamad. Sheffield: Sheffield Academic Press

Binford, L.R. 1981. Behavioral archaeology and the 'Pompeii premise'. Journal of Anthropological Research 37, 195-208

Byrd, B. 1989. The Natufian Encampment at Beidha. Moesgaard: Jutland Archaeological Society Publications XXIII:1

Byrd, B. 1994. Public and private, domestic and corporate: the emergence of the southwest Asian village. American Antiquity 59 (4), 639-66

Byrd, B. forthcoming. The Neolithic Village of Beidha: Architecture, Occupation History and Spatial Organization. London: British Academy Monograph

Byrd, B. \& Banning, E.B. 1988. Southern Levantine pier houses: intersite architectural patterning during the PrePottery Neolithic B. Paléorient 14 (1), 65-72

Byrd, B. \& Monahan, C. 1995. Death, mortuary ritual and Natufian social structure. Journal of Anthropological Archaeology 14, 251-87

CAD 1957-date. The Chicago Assyrian Dictionary. Chicago: University Press

Clark, J. \& Blake, M. 1993. The power of prestige: competitive generosity and the emergence of rank societies in lowland Mesoamerica. In E. Brumfiel \& J. Fox (eds), Factional Competition and Political Development in the New World, 17-30. Cambridge: University Press

Codere, H. 1950. Fighting with Property. New York: J.J. Augustin

Colledge, S. 1994. Plant Exploitation on Epipalaeolithic and Early Neolithic Sites in the Levant. Unpublished Ph.D. dissertation, University of Sheffield. Ann Arbor, Michigan: University Microfilms

Dahlberg, F. 1981. Woman the Gatherer. New Haven: Yale University Press

Damerow, P. 1996. Food production and social status as documented in proto-cuneiform texts. In Wiessner \& Schiefenhövel 1996, 149-70
David, N., Sterner, J. \& Gavua, K. 1988. Why pots are decorated. Current Anthropology 29, 365-88

Davidson, J. 1997. Courtesans and Fishcakes: the consuming passions of classical Athens. London: Fontana Press

Dollfus, G. forthcoming. La Travaille de la Pierre à Mallaha. Paris \& Jerusalem: Mémoires et Travaux du Centre de Recherche Préhistoriques Français de Jerusalem

Dorrell, P. 1983. Appendix A: stone vessels, tools and objects. In Kenyon \& Holland 1983, 485-575.

Douglas, M. 1966. Purity and Danger. London: Routledge \& Kegan Paul

Douglas, M. 1972. Deciphering a meal. Daedalus 1972, 61-81

Douglas, M. 1984. Food in the Social Order. New York: Russell Sage Foundation

Edwards, P. 1991. Wadi Hammeh 27: an early Natufian site at Pella, Jordan. In Bar-Yosef \& Valla 1991, 123-48

Edwards, P., Bourke, S., Colledge, S., Head, J. \& Macumber, P. 1988. Late Pleistocene prehistory in the Wadi al-Hammeh, Jordan Valley. In A.N. Garrard \& H.G. Gebel (eds), The Prehistory of Jordan, 525-65. Oxford: British Archaeological Report S396

Engels, F. 1972 [1884]. The Origin of the Family, Private Property and the State. New York: New World Paperbacks

Esin, U., Biçakçi, E., Özbasaran, M., Balkan-Atli, N., Berker, D., Yagmur, I. \& Atli, A. 1991. Salvage excavations at the pre-pottery neolithic site of Asliki Höyük in central Anatolia. Anatolica 17, 123-74

Farb, P. \& Armelagos, G. 1980. Consuming Passions: the Anthropology of Eating. Boston: Houghton Mifflin

Firth, R. 1957. We the Tikopia. London: Allen Unwin

Flannery, K.V. 1972. The origin of the village as a settlement type in Mesoamerica and the Near East: a comparative study. In P. Ucko, R. Tringham \& G. Dimbleby (eds), Man, Settlement and Urbanism, 23-53. London: Duckworth

Forest, J.-D. 1996. Le PPNB de Çayönü et de Nevali Çori: pour une approche archéo-ethnologique de la néolithisation du Proche-Orient. Anatolica Antiqua 4, 1-31

Foster, B. 1982. Umma in the Sargonic Period. New Haven: Connecticut Academy of Sciences, Memoir 20

Garfinkel, Y. 1993. Gesher. In M. Avi-Yonah \& E. Stern (eds), New Encyclopedia of Archaeological Excavations in the Holy Land, 492-3. Jerusalem: Israel Exploration Society

Garrard, A. 1999. Charting the emergence of cereal and pulse domestication in southwest Asia. Environmental Archaeology 4, 57-76

Garstang, J. \& Garstang, J. 1948. The Story of Jericho. London: Marshall, Morgan \& Scott

Gebel, H.-G., Kafafi, Z. \& Rollefson, G. 1997a. The Prehistory of Jordan II: Perspectives from 1997. Berlin: Ex Oriente

Gebel, H.-G., Bienert, H.-D., Kramer, T., Muller-Neuhof, B., Neef, R., Timm, J. \& Wright, K. 1997b. Ba'ja hidden in the Petra mountains: preliminary results of the 1997 season. In Gebel et al. 1997a, 221-62 


\section{K. Wright SOCIAL ORIGINS OF COOKING \& DINING, EARLY VILLAGES, WESTERN ASIA}

Gero, J. \& Conkey, M. 1991. Engendering Archaeology: women and prehistory. Oxford: Blackwell

Goody, J. 1976. Production and Reproduction. Cambridge: University Press

Goody, J. 1982. Cooking, Cuisine and Class. Cambridge: University Press

Gopher, A. 1997. Ground stone tools and other stone objects from Netiv Hagdud. In Bar-Yosef \& Gopher 1997, 151-76

Gopher, A. \& Orrelle, E. 1995. The Ground Stone Assemblages of Munhata, a Neolithic Site in the Jordan Valley, Israel: a report. Paris: Cahiers des Missions Archéologiques Françaises en Israel, Association Paléorient

Goren, Y. \& Goldberg, P. 1991. Petrographic thin sections and development of Neolithic plaster production in northern Israel, Journal of Field Archaeology 18, 131-8

Goren, Y., Segal, I. \& Bar-Yosef, O. 1993. Plaster artefacts and the interpretation of Nahal Hemar Cave. Mitekufat Haeven 25, 120-31

Goring-Morris, A.N., Goren, Y., Horwitz, L., Hershkovitz, I., Lieberman, R. \& Bar-Yosef, D. 1994. The 1992 season of excavations at the pre-pottery Neolithic B settlement of Kfar Hahoresh. Mitekufat Haeven 26, 74-121

Gosden, C. \& Hather, J. 1999. The Prehistory of Food: appetites for change. New York: Routledge

Harris, R. 1975. Ancient Sippar. Amsterdam: Nederlands Historisch-Archaeologisch Institut te Istanbul

Hastorf, C. 1991. Gender, space and food in prehistory. In Gero \& Conkey (eds) 1991, 132-62

Hastorf, C. 1998. The cultural life of domestic plant use. Antiquity 72 (278), 773-82

Hattox, R.S. 1985. Coffee and Coffeehouses: the origins of a social beverage in the medieval Near East. Seattle \& London: University of Washington Press

Hauptmann, H. 1993. Ein Kultgebäude in Nevali Çori. In M. Frangipane et al. (eds), Between the Rivers and Over the Mountains, 37-69. Rome: Universita di Roma 'La Sapienza'

Hayden, B. \& Cannon, A. 1984. The Structure of Material Systems: ethnoarchaeology in the Maya Highlands. Washington, D.C.: Society for American Archaeology Paper 3

Hershkovitz, I. 1989. People and Culture in Change. Oxford: British Archaeological Report S508

Hillier, B. \& Hanson, J. 1984. The Social Logic of Space. Cambridge: University Press

Hillman, G. in press. The archaeobotanical remains from Abu Hureyra. In A.M.T. Moore (ed.), Village on the Euphrates: the excavation of Abu Hureyra. Oxford: University Press

Hillman, G.C., Colledge, S. \& Harris, D. 1989. Plant-food economy during the Epipalaeolithic period at Tell Abu Hureyra, Syria: dietary diversity, seasonality and modes of exploitation. In D. Harris \& G.C. Hillman (eds), Foraging and Farming, 240-68. London: Unwin Hyman

Hillman, G.C. and Davies, S. 1990. Measured domestication rates in wild wheat and barley under primitive cultivation and their archaeological implications. Journal of World Prehistory 4, 157-222
Hodder, I. 1990. The Domestication of Europe. Oxford: Blackwell

Hodder, I. (ed.) 1997. On the Surface. Cambridge: MacDonald Institute Publications

Hopf, M. 1983. Jericho plant remains. In Kenyon \& Holland 1983, 576-621

Horwitz, L., Tchernov, E., Ducos, P., Becker, C., Drisch, A., Martin, L. and Garrard, A. 1999. Animal domestication in the southern Levant. Paléorient 25 (2), 61-78

Joffe, A. 1998. Alcohol and social complexity in ancient western Asia. Current Anthropology 39 (3), 297-322

Kafafi, Z. \& Rollefson, G. 1994. 'Ain Ghazal 1993-1994. Biblical Archaeologist 57 (4), 239-41

Kafafi, Z. \& Rollefson, G. 1995. The 1994 excavations at 'Ain Ghazal: preliminary report. Annual of the Department of Antiquities of Jordan 39, 13-29

Kent, S. 1990. Domestic Architecture and the Use of Space: an interdisciplinary cross-cultural study. Cambridge: University Press

Kenyon, K. 1979. Archaeology in the Holy Land. London: Ernest Benn

Kenyon, K. \& Holland, T. 1981. Excavations at Jericho III. The Architecture and Stratigraphy of the Tell. London: British School of Archaeology in Jerusalem

Kenyon, K. \& Holland, T. 1983. Excavations at Jericho V. The Pottery Phases of the Tell and Other Finds. London: British School of Archaeology in Jerusalem

Kirkbride, D. 1966. Five seasons at the Pre-Pottery Neolithic village of Beidha in Jordan: a summary. Palestine Exploration Quarterly 98, 8-72

Kirkbride, D. 1975. Umm Dabaghiyah, a fourth preliminary report. Iraq 37, 3-10

Kislev, M. 1997. Early agriculture and paleoecology of Netiv Hagdud. In Bar-Yosef \& Gopher 1997, 209-36

Kramer, C. 1982. Village Ethnoarchaeology. New York: Academic Press

Kuijt, I. 1995. Pre-pottery Neolithic A settlement variability: evidence for sociopolitical developments in the southern Levant. Journal of Mediterranean Archaeology 7, 165-92 Leacock, E.B. 1972. Introduction. In Engels 1972, 7-67

Lechevallier, M. 1978. Abou Gosh et Beisamoun. Paris: Mémoires et Travaux du Centre de Recherche Français à Jerusalem 2

Lechevallier, M. \& Ronen, A. 1985. Le site NatoufienKhiamien de Hatoula, près de Latroun, Israel. Fouilles 1980-1982. Paris: Cahiers du Centre Français de Recherche à Jerusalem 1

Lechevallier, M., Philibert, D., Ronen, A. \& Samzun, A. 1989. Une occupation khiamienne et sultanienne à Hatoula? Paléorient 15, 1-10

Lee, R. \& De Vore, I. 1968. Man the Hunter. Chicago: Aldine

Levi-Strauss, C. 1963. Structural Anthropology. New York: Basic Books

Levi-Strauss, C. 1969. The Raw and the Cooked. New York: Harper \& Row

Levi-Strauss, C. 1978. The Origin of Table Manners. London: Jonathan Cape 
Maekawa, K. 1980. Female weavers and their children in Lagash: pre-Sargonic and Ur III. Acta Sumerologica 4, 81-125

Mahasneh, H. 1997. The 1995 season at the Neolithic site of es-Sifiya, Wadi Mujib, Jordan. In Gebel et al. 1997a, 203-14

Malinowski, B. 1954. Magic, Science and Religion and Other Essays. Garden City, New York: Anchor Books

Mallos, T. 1979. The Complete Middle East Cookbook. Sydney: Summit Books

Mead, M. 1928. Coming of Age in Samoa. New York: American Museum of Natural History

Mead, M. 1947. The Mountain Arapesh II: Socio-economic life. Anthropological Papers of the American Museum of Natural History, 49 (3)

Mellaart, J. 1966. Excavations at Çatal Hüyük 1965: fourth preliminary report. Anatolian Studies 16, 165-91

Mellaart, J. 1970. Excavations at Hacilar I-II. Edinburgh: University Press

Messer, E. 1984. Anthropological perspectives on diet. Annual Review of Anthropology 13, 205-49

Miller, R.J. 1982. Manos, metates and tennis elbow: degenerative joint disease in the prehistoric Southwest. American Journal of Physical Anthropology 57, 210-210

Molleson, T. 1989. Seed preparation in the Mesolithic: the osteological evidence. Antiquity 63, 356-62

Molleson, T. 1994. The eloquent bones of Abu Hureyra. Scientific American August 1994, 70-5

Moore, H. 1985. Space, Text and Gender. Cambridge: University Press

Nissen, H., Muheisen, M., Gebel, H.-G., Becker, C., Neef, R., Pachar, H. \& Qadi, N. 1987. Report on the first two seasons of excavations at Basta 1986-1987. Annual of the Department of Antiquities of Jordan 31, 79-119

Noy, T. 1979. Stone cupholes and querns from Gilgal I: a pre-pottery Neolithic A site in Israel. Paléorient 5, 233-8

Noy, T. 1989a. Some aspects of mortuary behavior at Nahal Oren. In Hershkovitz 1989, 53-8

Noy, T. 1989 b. Gilgal I, a pre-pottery Neolithic site, Israel, the 1985-1987 seasons. Paléorient $15,11-18$

Noy, T. 1991. Art and decoration of the Natufian at Nahal Oren. In Bar-Yosef \& Valla 1991, 557-68

Noy, T., Legge, A. \& Higgs, E. 1973. Recent excavations at Nahal Oren, Israel. Proceedings of the Prehistoric Society 39, 75-99

Noy, T., Schuldenrein, P. \& Tchernov, E. 1980. Gilgal, a pre-pottery Neolithic A site in the lower Jordan valley. Israel Exploration Journal 30, 63-82

Oppenheim, A.L. 1967. Letters from Mesopotamia. Chicago: University Press

Ortner, S. 1972. Is female to male as nature is to culture? Feminism Studies 1, 5-31

Perrot, J. 1966a. Le gisement natoufien de Mallaha (Eynan), Israel. L'Anthropologie 70, 437-84

Perrot, J. 1966b. La troisième campagne de fouilles à Munhata 1964. Syria 43, 49-63

Peterson, J. 1994. Changes in the sexual division of labour in the prehistory of the southern Levant. Unpublished Ph.D. dissertation, Arizona State University. University Microfilms, Ann Arbor
Peterson, J. 1997. Tracking activity patterns through skeletal remains: a case study from Jordan and Palestine. In Gebel et al. 1997a, 475-92

Radcliffe-Brown, A. 1952. Structure and Function in Primitive Society. New York: Free Press

Rappaport, R. 1968. Pigs for the Ancestors: ritual in the ecology of a New Guinea People. New Haven, Connecticut: Yale University Press

Reiter, R. 1975. Men and women in the south of France: public and private domains. In R. Reiter (ed.), Toward an Anthropology of Women, 252-82. New York: New School of Social Research

Richards, A. 1939. Land, Labour and Diet in Northern Rhodesia: An Economic Study of the Bemba Tribe. London: Routledge

Rollefson, G. 1983a. The 1982 excavations at 'Ain Ghazal: preliminary report. Annual of the Department of Antiquities of Jordan 27, 1-15

Rollefson, G. 1983b. Ritual and ceremony at Neolithic 'Ain Ghazal (Jordan). Paléorient 9 (2), 29-38

Rollefson, G. 1984. 'Ain Ghazal: an early Neolithic community in highland Jordan, near Amman, Bulletin of the American Schools of Oriental Research 255, 3-14

Rollefson, G. 1985. The 1983 season at the early Neolithic site of 'Ain Ghazal. National Geographic Research 1985, $44-62$

Rollefson, G., 1990. The uses of plaster at Neolithic 'Ain Ghazal, Jordan. Archaeomaterials 4, 33-54

Rollefson, G. 1997. Changes in architecture and social organization at 'Ain Ghazal. In Gebel et al. 1997a, 287-307

Rollefson, G. \& Kohler-Rollefson, I. 1989. The collapse of early Neolithic settlements in the southern Levant. In Hershkovitz 1989, 73-90

Rollefson, G. \& Leonard, A. 1983. Excavations at PPNB 'Ain Ghazal. Annual of the Department of Antiquities of Jordan 27, 411-13

Rollefson, G. \& Simmons, A. 1984. The 1983 season at 'Ain Ghazal: preliminary report. Annual of the Department of Antiquities of Jordan 28, 13-30

Rollefson, G. \& Simmons, A. 1986. The Neolithic village of 'Ain Ghazal, Jordan: preliminary report on the 1984 season. Bulletin of the American Schools of Oriental Research Supplement 24, 145-64

Rollefson, G., Kafafi, Z. \& Simmons, A. 1990. The 1988 season at 'Ain Ghazal: a preliminary report. Bulletin of the American Schools of Oriental Research Supplement 27, 95-116

Rollefson, G., Simmons, A. \& Kafafi, Z. 1992. Neolithic cultures at 'Ain Ghazal, Jordan. Journal of Field Archaeology 19, 443-70

Sahlins, M. 1972. Stone Age Economics. Chicago: Aldine Press

Salonen, A. 1966. Die Hausgerate der alten Mesopotamier nach sumerisch-akkadischen Quellen. Helsinki: Annales Academiae Scientiarum Fennicae B144

Schick, T. 1988. Cordage, basketry and fabrics. In Bar-Yosef \& Alon 1988, 31-43 


\section{K. Wright SOCIAL ORIGINS OF COOKING \& DINING, EARLY VILLAGES, WESTERN ASIA}

Schick, T. 1997. Miscellaneous finds: a note on the perishable items from Netiv Hagdud. In Bar-Yosef \& Gopher 1997, 197-200

Schmidt, K. 1995. Investigations in the upper Mesopotamian early Neolithic: Göbekli Tepe and Gürcutepe. Neo-Lithics 95 (2), 9-10

Schmidt, K. 1997. Snakes, lions and other animals: the Urfa project 1997. Neo-Lithics 97 (3), 8-9

Schmidt, K. 1998. Beyond daily bread: evidence of early Neolithic ritual from Göbekli Tepe. Neo-Lithics 98 (2), 1-5

Schneider, N. 1926. Die Lohnbücher der Mühle von Sagdana. Archiv für Orientforschung 3, 121-5

Sherratt, A. 1981. Plough and pastoralism: aspects of the secondary products revolution. In I. Hodder, G. Isaac \& N. Hammond (eds), Pattern of the Past, 261-305. Cambridge: University Press

Speth, J. 1990. Seasonality, resource stress and food-sharing in so-called egalitarian foraging societies. Journal of Anthropological Archaeology 9, 148-88

Stekelis, M. \& Yizraely, T. 1963. Excavations at Nahal Oren, preliminary report. Israel Exploration Journal 13, 1-12

Tchernov, E. 1991. Biological evidence for human sedentism in southwest Asia during the Natufian. In BarYosef \& Valla 1991, 315-40

Tiger, L. 1970. Men in Groups. New York: Vintage Books

Turnbull, C. 1965. Wayward Servants: the Two Worlds of the African Pygmies. Garden City, New York: Natural History Press

Valla, F. 1988. Aspects du sol de l'abri 131 de Mallaha (Eynan). Paléorient 14, 283-96

Valla, F. 1991. Les natoufiens de Mallaha et l'espace. In BarYosef \& Valla 1991, 111-22

Valla, F., Bar-Yosef, O., Smith, P., Tchernov, E. \& Desse, J. 1986. Un nouveau sondage sur la terrasse d'El-Ouad, Israel. Paléorient, 12, 21-38

Valla, F., Le Mort, F. \& Plisson, H. 1991. Les fouilles en cours sur la terrasse d'Hayonim. In Bar-Yosef \& Valla 1991, 93-110
Valla, F., Plisson, H. \& Buxo i Capdevila, R. 1989. Notes préliminaires sur les fouilles en cours sur la terrasse d'Hayonim. Paléorient, 15, 245-58

Waheeb, M. \& Fino, N. 1997. Ayn el-Jammam: a Neolithic site near Ras en-Naqb, southern Jordan. In Gebel et al. 1997a, 215-19

Wiessner, P. \& Schiefenhövel, W. 1996. Food and the Status Quest: an interdisciplinary perspective. Oxford: Berghahn Books

Willson, M. 1949. Nyakyusa age-villages. Journal of the Royal Anthropological Institute 79, 21-5

Wright, K. 1992. Ground Stone Assemblage Variations and Subsistence Strategies in the Levant, 22,000 to 5500 BP. Unpublished Ph.D. dissertation, Yale University, University Microfilms, Ann Arbor.

Wright, K. 1993. Early Holocene ground stone assemblages in the Levant. Levant 25, 93-111

Wright, K. 1994. Ground stone tools and hunter-gatherer subsistence in southwest Asia: implications for the transition to farming. American Antiquity 59 (2), 238-63

Wright, K. 1998. Dhuweila: Ground stone. In Betts 1998, 121-34

Wright, K. forthcoming. Ground stone artefacts from Beidha: toolkits, activities and social implications. In B. Byrd (ed.), The Neolithic Village of Beidha: Architecture, Occupation History and Spatial Organization. London: British Academy Monograph

Yakar, R. \& Hershkovitz, I. 1988. The modelled skulls. In Bar-Yosef \& Alon 1988, 59-63

Yentsch, A. 1991. The symbolic divisions of pottery: sexrelated attributes of English and Anglo-American household pots. In R. McGuire \& R. Paynter (eds), The Archaeology of Inequality, 192-230. Oxford: Blackwell

Zeist, W. van \& Bakker-Heeres, J. 1985. Some economic and ecological aspects of the plant husbandry of Tell Aswad. Paléorient 5, 161-9 